\title{
Psychological interventions of virtual gamification as a motivational basis: A mixed-method systematic review
}

Joy Xu ( $\sim$ joyjxu@gmail.com )

McMaster University https://orcid.org/0000-0002-3233-2371

Aaron Lio

University of Toronto

Harshdeep Dhaliwal

McMaster University

Sorina Andrei

McMaster University

Shakthika Balakrishnan

University of Waterloo

Uzhma Nagani

McMaster University

Sudipta Samadder

McMaster University

\section{Systematic Review}

Keywords: Academia, Academic performance, Adults, COVID-19, Gamification, Intervention, Intrinsic motivation, Mobile application, Motivation, Motivational intervention, Online learning, Productivity, Psychological intervention, Psychology, Students, Systematic review, Virtual, Virtual, gamification, Webbased, Young adults

Posted Date: June 10th, 2021

DOI: https://doi.org/10.21203/rs.3.rs-607400/v1

License: (a) (1) This work is licensed under a Creative Commons Attribution 4.0 International License. Read Full License 


\section{Psychological interventions of virtual gamification as a motivational basis: A mixed-method systematic review}

Mar 30, 2021

Joy $\mathrm{Xu},{ }^{1}$ Aaron Lio, ${ }^{2}$ Harshdeep Dhaliwal, ${ }^{1}$ Sorina Andrei, ${ }^{1}$ Shakthika Balakrishnan, ${ }^{3}$ Uzhma Nagani, ${ }^{1}$ Sudipta Samadder ${ }^{1}$

${ }^{1}$ McMaster University, Hamilton, ON, Canada

${ }^{2}$ St Robert CHS, Thornhill, ON, Canada

${ }^{3}$ University of Waterloo, Waterloo, ON, Canada

Contact Info: joyxu@gmail.com

\section{ABSTRACT}

Background

Students constantly seek ways to improve productivity within academia. With the advancement of technology in the recent decade, virtual implementations may provide additional support for student productivity, particularly during the COVID-19 pandemic with online learning. One of the virtual realms for motivation include gamification, which has potential as an effective tool to further bolster an individual's source of intrinsic motivation.

\section{Methods}

Using a convergent integrated synthesis approach, qualitative and quantitative studies were extracted from APA PsycInfo, ProQuest, and IEEE for relevance to virtual gamification and intrinsic motivation. Studies were reviewed based on a pre-determined and piloted screening tool. Included studies were published between 1990 and 2020 in English within Asia, North America, and/or Europe. Only systematic reviews, randomized control trials (RCTs), meta-analysis, and grey literature were included. Study screening, extraction, and quality appraisals using the Mixed Methods Appraisal Tool (MMAT) were performed independently among two authors. Disagreements following reconciliation between two authors were settled by a third author. Heterogeneity in study designs, outcomes, and measurements precluded meta and statistical analyses; thus, a qualitative analysis of studies was provided.

Results

Based on the appraised articles, gamification improves intrinsic motivation through badges, social interactions, points, and leaderboards. Experimental studies also displayed a correlation between learning behaviour.

\section{Conclusion}

The data exhibited an increase in intrinsic motivation due to gamification features, which can be integrated within a virtual context to enhance motivation with potential for application towards online learning settings.

Key Words 
"Gamif*" AND "Educat*” AND "Psych*" AND "Student" NOT "Econ*" OR "Motivat*" OR "Self-determination theory" AND "autonom*" AND "intrinsic motivat*" NOT "extrinsic motivat*"

\section{INTRODUCTION}

Academic motivation is a major field in psychology, as it explores the correlation between student motivation and academic success. Research has discovered that the presence and integration of various forms of motivation, such as intrinsic motivation, were required to maintain and improve academic performance [1], as only $48.9 \%$ of students remained interested in initiated tasks and $36.9 \%$ of students did not postpone solving difficult problems, such as math problems [2]. The Organisation for Economic Co-operation and Development (OECD) also measured that $27 \%$ of students in the member countries have skipped at least one class within two weeks, partly attributing to a lack of engagement at school [3]. Across OECD countries, $56 \%$ of students reported that they did not give up easily when presented with a problem [2]. Intrinsic motivation to learn mathematics was low in the 2012 OECD assessment, with $38 \%$ of students engaging in mathematics for personal enjoyment [2]. Furthermore, $40 \%$ of students reported feeling disengaged in class, paying little attention to lessons, and putting in minimal effort [4]. Student cohort studies also displayed a $14 \%$ decline in intrinsic motivation when comparing students between the ages 11 to 16 , thereby, exhibiting a decrease in motivation as adolescent populations age [5].

Within motivation, two categories have been observed in the workplace and academia: extrinsic and intrinsic motivation. The self-determination theory introduces extrinsic and intrinsic motivation, in which the relationship between personality, motivation, and optimal functioning is analysed [6]. Deci and Ryan's theory of motivation further elaborates on extrinsic motivation as a behaviour reinforced by external sources ranging from materialistic objects to standardized achievements (such as certificates, financial compensation, or academic grades) [6]. Extrinsic motivation applies operant conditioning from behavioural psychology by using external stimuli to increase or decrease the frequency of behaviours [7]. Thus, extrinsic motivation encourages individuals to complete a task by focusing on the outcome rather than the process. Extrinsic motivation promotes productivity in individuals, but it is unlikely to motivate students in the long-term [8]. In contrast, intrinsic motivation develops an internal drive to engage in activities based on an individual's motives, goals, values, and personal interests [6]. A significant purpose of intrinsic motivation is to practice and meet individualistic needs for autonomy, competence, and relatedness, with students experiencing a $15.2 \%$ increase in academic achievement when autonomous motivation improves by $1 \%$ [9]. Intrinsic motivation allows individuals to develop a passion for tasks and subsequently enhances productivity. Nevertheless, intrinsic motivation is limited in its application settings, as there are many circumstances in which individuals will not enjoy the task they are required to complete [10]. One potential solution to this limitation is to incorporate gamification into such educational settings. 
Gamification theory is defined as the implementation of video game elements in a non-gaming setting to improve individual engagement [11]. Gamification theory makes use of the entertainment-focused design of video games to alter the attitude and behaviour of learners. The components of gamification include the goal of the "game", the challenge, and the reward, which can be in the form of badges, points, or trophies [12]. While it is not a new concept, attention towards gamification has increased significantly in the last 15 years as a result of several factors, like easier access to gaming mediums and affordable technology [12]. Gamification has been used in offices, academia, and by companies to increase customer interaction. Nike demonstrates the use of gamification through their Nike + app, where individuals are encouraged to participate in fitness challenges to earn badges and trophies. The gamified approach of the app has made Nike+ one of the top fitness apps [13]. Furthermore, implementing gamification in the workplace has been effective in improving productivity, with $83 \%$ of workers feeling motivated to accomplish tasks after undergoing gamified employee training, $88 \%$ of employees feeling happier at work, and $89 \%$ believing they would be more productive if work included more gaming elements [14]. Gamified training softwares are used to teach courses, such as customer support training and project management essentials, by building employee skills in an interactive and engaging manner [15]. In the education sector, gamification is suggested to increase positive attitudes towards learning by increasing the willingness of students to take advantage of educational material [16]. As a result, $11 \%$ of learners displayed higher factual knowledge levels and $9 \%$ showed increased retention rates after gamification [17]. Gamification has become increasingly popular in marketing, healthcare, human resources, training, environmental protection, well-being, and education [18]. The value of the global gamification market grew to almost 11.94 billion USD in 2021 from 4.91 billion USD in 2016 [19]. Many corporations invested in gamification software for employee training and to maintain customer satisfaction with the services provided [20]. In particular, educational programs are incorporating gamification techniques to improve student engagement and motivation. A 2015 survey on gamification theory revealed that the education field generated the most research on the topic, contributing to $26 \%$ of the research conducted [12]. There is great interest in the virtual applications of gamification [21], evident with the recent surge of research concerned with the theory's implications, seen in 105 new publications on virtual gamification in education in 2020 compared to 3 publications in 2013 on PubMed. Many empirical studies evaluated the effectiveness of various gamification elements by observing changes in student motivation, engagement, performance, collaboration, participation, and satisfaction [12]. In the survey conducted by Seaborn and Fels, the authors found that $61 \%$ of findings from 31 papers reported positive results regarding the effectiveness of gamification while $39 \%$ had mixed results [12]. Similarly, $73 \%$ of the 11 comparative studies reported positive results and $27 \%$ were mixed. Moreover, gamification is a useful educational tool for its long-term contributions to behavioural patterns for learning. Through the use of gamification, students view progress as an achievement, thus, increasing intrinsic motivation. Students are encouraged to focus on completing achievable 
goals rather than focusing on an extrinsic metric of performance [12]. Thereby, learning becomes a durable and engaging activity, and students build resilience to failure. Gamification serves as a potential solution to break procrastination habits and reinforces consistency in working towards achievable goals [22].

Furthermore, online-based gamification introduces gamification to a population already immersed in technology [23]. 90\% of teenagers in the United States play video games either on a game console, computer, or smartphone [24]. Resources for technology-based programs are largely accessible both inside and outside the classroom in developed countries. $87 \%$ of households in urban areas and $81 \%$ of households in rural areas within developed countries have access to computers and/or the internet [25]. In developing countries, $65 \%$ of households in urban areas and $28 \%$ of households in rural areas have access to computers and/or the internet [25]. As such, developing countries will be omitted from this systematic review because of technological constraints and high levels of variance, when compared to developed countries.

This mixed-method systematic review focuses on gamification's impact on intrinsic motivation. Intrinsic motivation is associated with academic success, and these techniques seek to improve student behaviour and attitude toward learning [26]. The drive to achieve internal goals (i.e. to obtain new skills) pushes students to perform well in examinations. Competition, immediate feedback, and storytelling are examples of gaming elements that are being used by researchers in developing gamification systems [27]. For example, gamification users can compete with one another to earn points by engaging in certain actions, such as commenting on the ideas of other users [27]. Points (units collected that reflect individual progress) and badges (icons earned through achievements) reward players for completing tasks and reaching goals, and achievements can be publicly displayed by ranking individuals on a leaderboard [12]. Levels, ranks, and checkpoints track learning progress and allow students to build on previous work. Acquiring experience points by completing activities in-game increases a student's level and displays progression in addition to recognition for diligence [12]. Group tasks and chats allow players to interact with and support each other. By building an online community, students can engage in discussions and build relationships with peers.

This systematic review seeks to address the concerns surrounding student motivation and engagement in education by reinforcing productive behaviours. These behaviours were promoted by identifying, appraising, and synthesizing all available studies related to this topic. The research targets declines in student motivation by studying the virtual gamification methods that can be implemented to enhance student motivation and engagement during the completion of cognitive tasks. Resulting research may lead to advancements in the field and provide information to the Felicity App. Felicity is an application targeting productivity in students. The application will incorporate gamification elements to improve intrinsic motivation, with a focus on students, to promote these habits. Therefore, this systematic review is also intended to analyze 
the relevant practical findings of research to incorporate elements that are most effective on a virtual platform, like Felicity. Since gamification is an unfamiliar topic, more empirical research and experimental replications must be conducted to further support the effectiveness of gamification. The literature has indicated a lack of statistical analyses and a lack of isolation of the gamification effect, noted through the absence of control groups [12].

The culmination of this review will guide the development of the Felicity App and address the potential challenges associated with student motivation through interventional methods. Following the synthesis of present literature, the Felicity App will be developed as a solution to promote productivity for users across the world. This application will be available to the public for further intervention analysis and promotion of its installation and use. In the future, there is potential for longitudinal studies to be conducted to measure the influence of Felicity on intrinsic motivation.

\section{METHOD}

A systematic review was performed to determine the influence of virtual gamification integration on student motivation within academia. The objective of this systematic review was to search available literature to identify effective gamification techniques. Chosen interventions from this systematic review will yield potential features on the Felicity app after screening, extraction, and quality appraisal of data in present literature. The selection procedure followed the Preferred Reporting Items for Systematic Review and Meta-Analyses (PRISMA) guidelines. The protocol of this systematic review was registered with PROSPERO (record ID: CRD42021234241). PROSPERO is an international database of prospectively registered systematic reviews in health and social care.

\section{Study Design \& Setting}

The purpose of this systematic review was to assess the effectiveness of virtual gamification methods in enhancing student intrinsic motivation and engagement in independent cognitive tasks. Rather than assessing all gamification techniques, this systematic review focused on the efficacy of virtual techniques, which can be integrated into a virtual application for greater global accessibility. The mixed methods design was used as it evaluates both qualitative and quantitative studies to establish breadth and depth within the systematic review [28]. The convergent integrated synthesis approach in a mixed methods design provides comprehensive assessment to the credibility, context, and utility of the studies while exploring diverse findings [29]. The mixed methods research design permits the examination of multidisciplinary data regarding gamification elements prevalent in motivational systems. The design also reveals a variety of findings, such as quantitative changes in grades and self-reported perceptions of satisfaction and motivation [12]. 
The demographic of interest encompasses students between the ages of 15-40 years residing in developed countries located in North America, Asia, and Europe, and included findings from all ethnicities. Research was collected from members of these regions as the majority of technological users reside in these countries with compatible devices necessary for the Felicity App (such as the internet and smartphones). Of the global youth population aged 15-24, internet users are proportioned as 90\% in the Americas, $96 \%$ in Europe, $84 \%$ in the Commonwealth of Independent States (CIS), 70\% in Asian and Pacific Islands, and 67\% in the Arab States [25]. In comparison, only $40 \%$ of youths from Africa use the internet. There is also a greater number of mobile phone subscriptions in the Americas, Europe, and Asia compared to Africa [25]. To manage this discrepancy in resources, research on virtual gamification techniques in regions outside of North America, Europe, and Asia were omitted from this systematic review. The geographical exclusion reduces variability to ensure that the participants in the reviewed studies share similar technological backgrounds and experiences. Australia was also excluded from the search due to the limited number of relevant research in its region.

\section{Search Strategy \& Criteria}

A diverse selection of literature, which included grey literature, was reviewed based on a predetermined inclusion/exclusion criteria. The criteria was established prior to the search and validated the contextual and scientific relevance of the data by developing a standardized expectation for the literature's content and experimental purpose.

Online databases that were searched in this systematic review include IEEE-Xplore, APA PsychInfo, and ProQuest from January 4, 2021, to January 16, 2021, by utilizing search strategies composed of key words related to the following: motivation, gamification, education, and psychology (refer to Appendix 1 for the search strategy). Regarding grey literature, the snowballing method was employed to identify and review the International Society for Technology in Education (ISTE) and Edutopia.org. Keywords including "gamification" and "motivation" were included to enhance search result relevance (refer to Appendix 2). Searches were further filtered to ensure relevance based on its date of production, as studies were set within the publication date range of January 1, 1990 to December 31, 2020.

The search strategy was developed by using keywords with booleans and truncations according to the population, intervention, comparison, outcomes, and context (PICOC) criteria. Specifically, "gamif*", "educat*", "psych*", "student", "motivat*", "self-determination theory", "autonom*", and "intrinsic motivat*" aided in the extraction of published literature, while "econ*" and "extrinsic motivat*" were used to exclude material through the "not" function. All of the keywords were used for a majority of our searches, although deviations in keyword usage are present in ProQuest, ISTE, and Edutopia.org searches. These searches excluded keywords, such as; "extrinsic motivat*" and "student" to broaden results, due to the limited number of relevant articles within the specified databases. A comprehensive set of sources were further 
processed using advanced search features to optimize relevance. Database-specific filters such as full-text, peer-reviewed, and journals were also applied, when applicable. The last search was conducted in January, 2021.

\section{Inclusion \& Exclusion}

Eligible studies included systematic reviews, randomized control trials (RCTs), and grey literature that were published in English between January 1, 1990 to December 31, 2020 within the field of psychology to provide a consistent baseline for searches by ensuring the relevance, accessibility, and quality of the preliminary literature. The populations of interest included students between the ages of 15 and 40 years old residing in developed countries within North America, Europe, and Asia. Since students in South America and Africa have significantly less access to the Internet and smart devices than those in the regions of interest, excluding these regions inhibited the wide discrepancy of resources from influencing the research conducted. The geographical exclusion created a control amongst acquired material. The focus of these studies was to explore the effect of gamification on personal, intrinsic motivation, and engagement using qualitative and quantitative data. Articles which reviewed one specific aspect of gamification in-depth, sampled individuals with mental or physical health diagnoses, and/or were unavailable online were excluded. The exclusion of these factors reduces bias as physical/mental conditions will uniquely affect a student's capacity to learn through gamification; thus data derived from students with such diagnoses can not be meaningfully compared amongst each other without significant confounding factors. The inclusion and exclusion criteria were predetermined. Refer to Fig. 1 for PICO analysis.

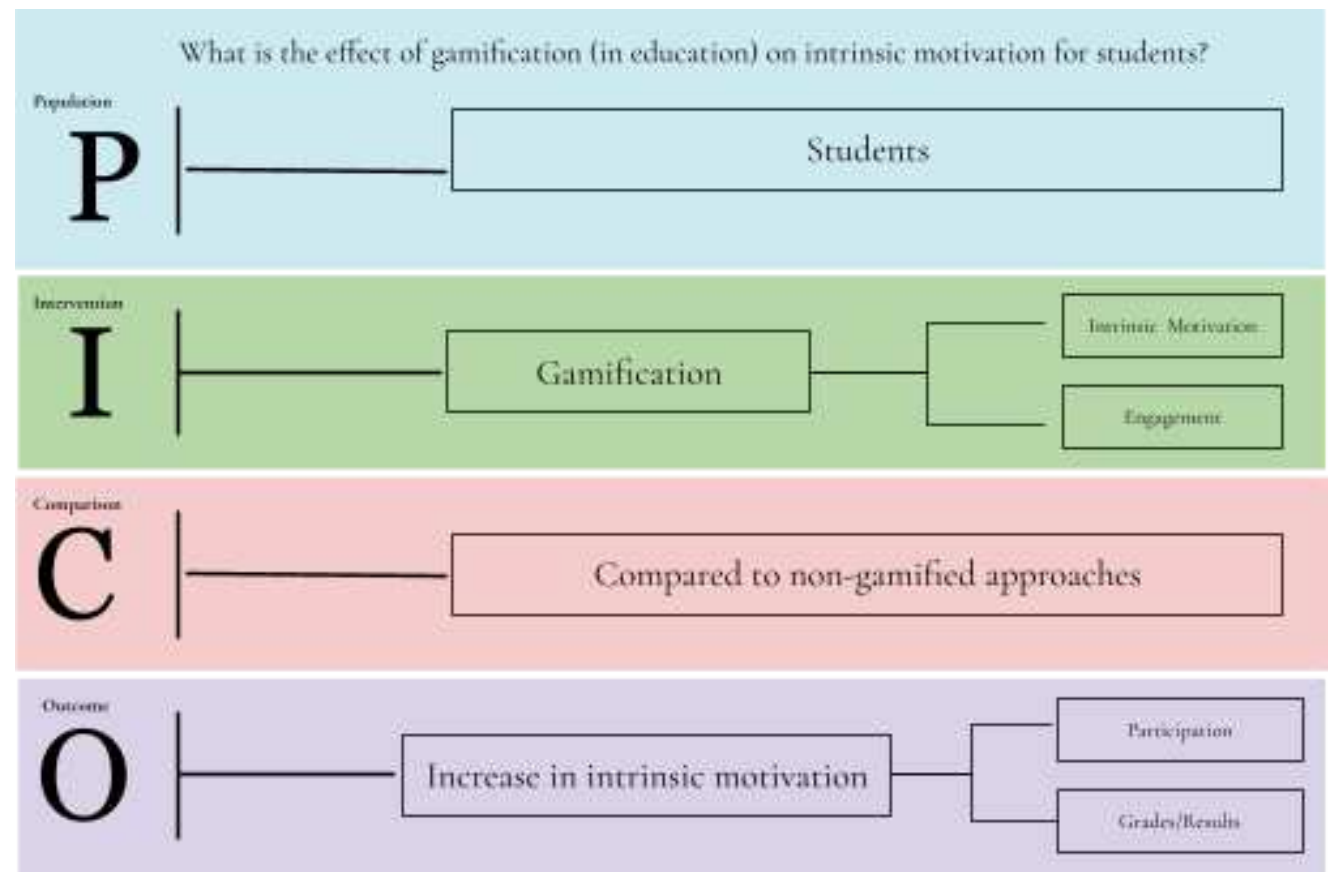

Fig. 1 Structural outline of PICO components that will be analyzed by this systematic review 


\section{Data Collection and Abstraction}

An abstract screening tool, consisting of 10 questions, was created and developed using the inclusion and exclusion criteria. These questions prompted the authors to analyze the literature's purpose, experimental design, methods, results, usage of gamification, and possible applications. The tool was tested by conducting a pilot screening trial in which five reviewers independently screened 24 abstracts and reconciled the individual scoring. The tool received an average accuracy score of $79 \%$, as approximately four out of five authors agreed on the relevance of each abstract to the research question. The pilot screening validated accuracy and prompted two authors (AL and HD) to revise and refine the screening tool to improve precision. Modifications to the tool were prompted by discussions during reconciliation. More objective questions were created to improve the accuracy of the scoring. The database search results were combined, and duplicate articles were removed manually using Endnote (version 8) prior to the screening phase.

\section{Identification of Relevant Studies and Data Extraction}

Using the abstract screening tool, two review authors (SB and SS) independently reviewed 381 articles, which included study abstracts and grey literature to determine suitability of studies for inclusion. After the removal of duplicates, the literature was screened based on its title, abstract, and summary, when applicable. Disagreements between the two independent screeners were reconciled by a third author (AL), followed by the full-text screening of eligible literature from the abstract screening phase. Hand searches were conducted from January 4, 2021-January 17, 2021. The abstract screening took place between January 18, 2021-January 23, 2021 and the grey literature screening took place between January 21, 2021-January 24, 2021. A list of excluded studies is shown in Appendix 3.

\section{Quality Appraisal}

All included studies were assessed for quality using the Mixed Methods Assessment Tool (MMAT). The MMAT is a quality appraisal tool designed for literature that includes qualitative, quantitative, and mixed methods studies [30]. The MMAT provides an effective measure to appraise a wide variety of empirical studies. The tool has been tested for reliability and content validity, however, the literature on the quality of the MMAT lacks consensus [31]. Several studies reported a large range of inter-rater agreement scores, which raises concerns regarding the reliability of the tool. To address this issue, the review authors (AL and SA) clarified some criteria used in the MMAT to obtain more objective ratings of the studies. Disagreements between the authors were discussed during reconciliation.

\section{Data Extraction}

Two authors (AL and SA) independently extracted data from the finalized list of studies that met the inclusion criteria. Data on study design, duration of intervention, participant information, type of data collected, and outcome of the intervention were recorded (for study characteristics, 
refer to Appendix 4). The two authors resolved any disagreements during reconciliation and disagreements were resolved by a third author when necessary.

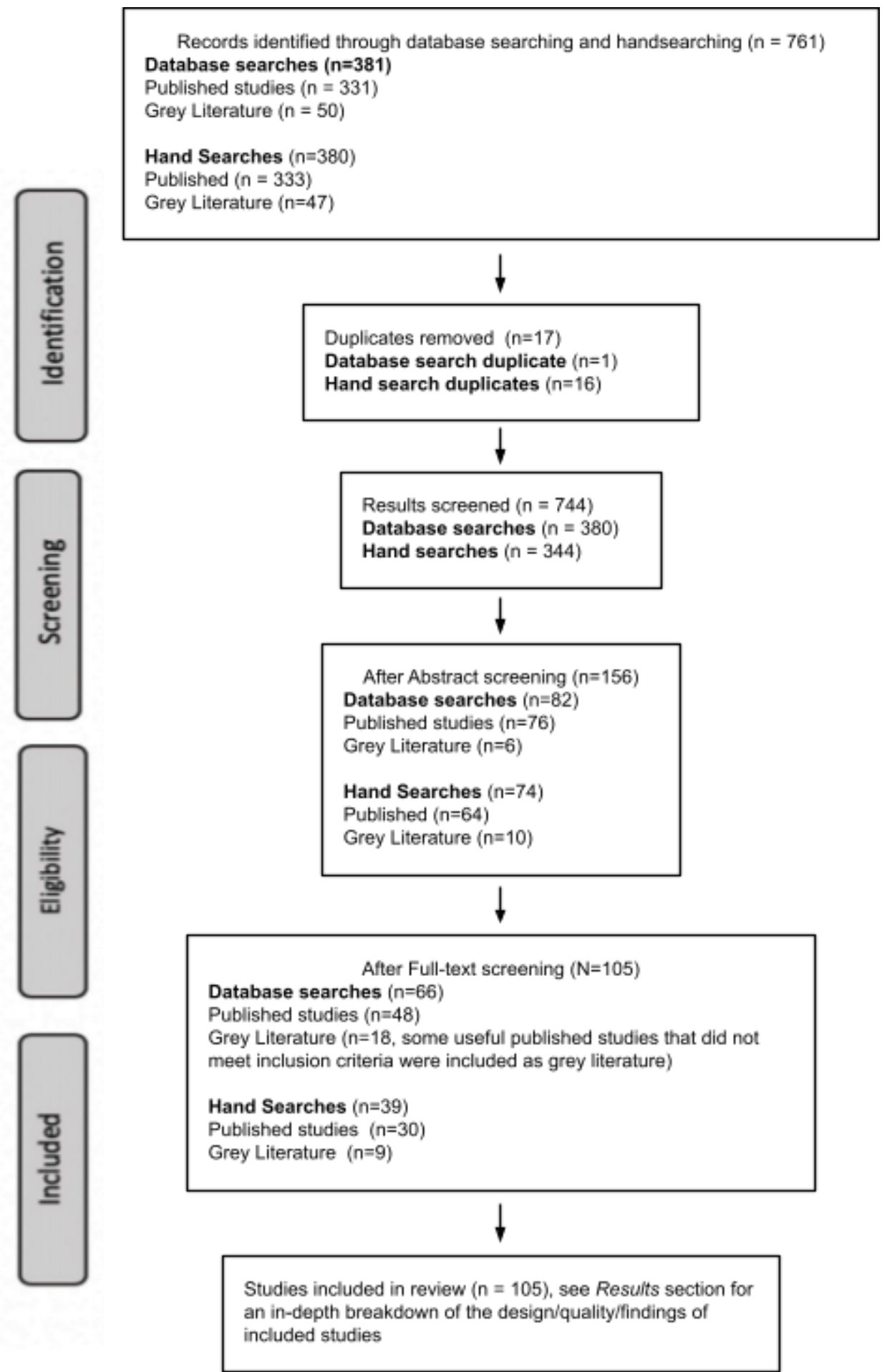

Fig. 2 Structural diagram of the screening and study selection processes completed 


\section{RESULTS}

\section{Study Selection}

The study selection and screening process is outlined in Fig. 2. 381 papers were identified from the database search, out of which 49 were grey literature, 331 were published studies, and 1 was a duplicate. Out of the 331 published studies 89 were retrieved from IEEE-Xplore, 8 from APA PsychInfo, and 231 from ProQuest. Out of the 49 grey literature, 14 were retrieved from the ISTE, and 36 were retrieved from Edutopia.org. Both the published and grey literature articles went through abstract screening and full-text screening. After abstract screening 82 articles remained in total, out of which 6 were grey literature and 76 were published studies. After full-text screening, 66 articles were left, out of which 18 were grey literature and 48 were published studies. Through hand searching, 380 articles were identified with 47 grey literature, 333 published studies, and 16 duplicates. After abstract screening 74 articles remained, out of which 10 were grey literature and 64 were published studies. Through full-text screening 39 articles remained with 9 grey literature and 30 published studies. In total, combining database and hand searches, 105 articles remained, out of which 27 were grey literature and 78 were published studies.

\section{Study Characteristics}

Of the 78 published studies included in this review, 36 studies are qualitative, 12 are quantitative descriptive, 15 are mixed methods, 8 are Randomized Control Trials (RCT), and 7 are non-randomized control trials. Furthermore, 15 studies are from the USA; 9 from Spain; 5 from Hong Kong; 4 from Portugal, Malaysia, France, Belgium, Bulgaria, Germany, and Iran contributed 3 studies, per country; Cyprus, Netherlands, Indonesia, Canada, Norway, and Taiwan provided 2 studies, per country. Also, 1 study from each of the following countries: Finland, Jamaica, Northern Ireland, Mexico, Croatia, South Korea, Hungary, Sweden, England, Italy, Scotland, Serbia, Switzerland, and Romania, were analyzed. Some studies are from more than one country. The collected data were grouped into four categories based on methods of collection: observational, questionnaire based, literature reviews, and data analysis. Out of the 78 papers, 33 are observation-based studies, 32 are questionnaire-based studies, 28 are literature reviews, and 2 are data analysis-based studies. Many studies are a combination of these data types and are incorporated in the values above. Studies were rated using the MMAT tool which has a 5 point scale, with 5 being the highest rank and 0 being the lowest rank. Out of the 78 articles appraised, 10 were rated 5, 22 articles were rated 4, 27 articles were rated 3, 10 articles were rated 2, and 9 articles were rated 1.

\section{Findings}

Findings from studies that were rated below 3 out of 5 using the MMAT tool were not considered. 59 articles were rated above 3, out of which $35(59.32 \%)$ found that gamification improves motivation, $3(5.08 \%)$ found that gamification did not improve motivation and 20 
$(33.9 \%)$ have either inconclusive results or results that were not relevant to the research question of this study.

\section{Outcomes}

Major outcomes were only considered for articles that were rated 5 out of $5(n=10)$ using the MMAT. 3 out of these 10 studies had outcomes that were not relevant to the research questions. The remaining 7 found that gamification improves intrinsic motivation. The outcomes from these articles are listed in Table 1.

Table 1 Findings and outcomes of articles that were rated $5 / 5(n=10)$

\begin{tabular}{|c|c|c|}
\hline Article & Finding & Outcome \\
\hline $\begin{array}{l}\text { Facey-Shaw L et al., 2018, } \\
\text { Educational Functions and Design } \\
\text { of Badge Systems: A Conceptual } \\
\text { Literature Review [32] }\end{array}$ & $\begin{array}{l}\text { Gamification improves } \\
\text { intrinsic motivation }\end{array}$ & $\begin{array}{l}\text { There are positive effects of } \\
\text { using badges on learning }\end{array}$ \\
\hline $\begin{array}{l}\text { Chan } \mathrm{G} \text { et al., } 2019 \text {, Motivational } \\
\text { strategies and approaches for } \\
\text { single and multi-player } \\
\text { exergames: a social perspective } \\
\text { [33] }\end{array}$ & $\begin{array}{l}\text { Gamification improves } \\
\text { intrinsic motivation }\end{array}$ & $\begin{array}{l}\text { Gamification motivated people } \\
\text { through social interaction as it } \\
\text { was more enjoyable }\end{array}$ \\
\hline $\begin{array}{l}\text { Herbert B et al., 2014, An } \\
\text { Investigation of Gamification } \\
\text { Typologies for Enhancing Learner } \\
\text { Motivation [34] }\end{array}$ & $\begin{array}{l}\text { Gamification improves } \\
\text { intrinsic motivation }\end{array}$ & $\begin{array}{l}\text { Good relationship between } \\
\text { gamification type and learner } \\
\text { behaviour }\end{array}$ \\
\hline $\begin{array}{l}\text { Dichev C \& Dicheva D, } 2017 \text {, } \\
\text { Gamifying education: what is } \\
\text { known, what is believed and what } \\
\text { remains uncertain: a critical } \\
\text { review [18] }\end{array}$ & $\begin{array}{l}\text { Not relevant to the } \\
\text { research question }\end{array}$ & $\begin{array}{l}\text { Research on gamification is } \\
\text { diverse; majority demographic } \\
\text { for studies is college students; } \\
\text { focus is on badges, points and } \\
\text { leaderboards; not enough } \\
\text { longitudinal research and } \\
\text { education context }\end{array}$ \\
\hline $\begin{array}{l}\text { Dicheva D et al., } 2015, \\
\text { Gamification in Education: A } \\
\text { Systematic Mapping Study [35] }\end{array}$ & $\begin{array}{l}\text { Gamification improves } \\
\text { intrinsic motivation }\end{array}$ & $\begin{array}{l}\text { Most reviewed papers showed } \\
\text { that gamification improves } \\
\text { learning }\end{array}$ \\
\hline $\begin{array}{l}\text { Mosalanejad L et al., } 2018 \text {, } \\
\text { Educational Game: A Fun and } \\
\text { team based learning in psychiatric } \\
\text { course and its effects on Learning }\end{array}$ & $\begin{array}{l}\text { Gamification improves } \\
\text { intrinsic motivation }\end{array}$ & $\begin{array}{l}\text { Gamification improved learning } \\
\text { through increasing engagement. }\end{array}$ \\
\hline
\end{tabular}




\begin{tabular}{|c|c|c|}
\hline Indicators [36] & & \\
\hline $\begin{array}{l}\text { Piras L et al., 2019, Design } \\
\text { Thinking and Acceptance } \\
\text { Requirements for Designing } \\
\text { Gamified Software [37] }\end{array}$ & $\begin{array}{l}\text { Gamification improves } \\
\text { intrinsic motivation }\end{array}$ & $\begin{array}{l}\text { Design thinking improves } \\
\text { effects of gamification }\end{array}$ \\
\hline $\begin{array}{l}\text { Saputro RE et al., 2019, A } \\
\text { gamification framework to } \\
\text { enhance students' intrinsic } \\
\text { motivation on MOOC [38] }\end{array}$ & $\begin{array}{l}\text { Gamification improves } \\
\text { intrinsic motivation }\end{array}$ & $\begin{array}{l}\text { New gamification platform } \\
\text { increases student intrinsic } \\
\text { motivation in online course } \\
\text { format }\end{array}$ \\
\hline $\begin{array}{l}\text { Zhang R, 2020, Game-based } \\
\text { self-regulated language learning: } \\
\text { Theoretical analysis and } \\
\text { bibliometrics [39] }\end{array}$ & $\begin{array}{l}\text { Not relevant to } \\
\text { research question }\end{array}$ & $\begin{array}{l}\text { Game Based Self-Regulated } \\
\text { Language Learning (GBSRLL) } \\
\text { has been receiving more } \\
\text { attention, specifically in the } \\
\text { fields of learning strategies and } \\
\text { the effect of GBSRLL on learner } \\
\text { states and its features. }\end{array}$ \\
\hline $\begin{array}{l}\text { Connolly TM et al., 2012, A } \\
\text { systematic literature review of } \\
\text { empirical evidence on computer } \\
\text { games and serious games [40] }\end{array}$ & $\begin{array}{l}\text { Not relevant to } \\
\text { research question }\end{array}$ & $\begin{array}{l}\text { Serious game studies used } \\
\text { quasi-experiments more, studies } \\
\text { of entertainment games used } \\
\text { quasi-experiments and surveys. } \\
\text { RCTs and qualitative designs } \\
\text { were uncommon. }\end{array}$ \\
\hline
\end{tabular}

\section{DISCUSSION}

This review provides a comprehensive examination of current literature regarding the effect of gamification on student intrinsic motivation in an academic setting. Generally, gamification is associated with increases in intrinsic motivation, which was recorded by observational, self-report, data analysis, or systematic review measures. The literature demonstrated this relationship, although there was variation in the presence and level of motivational improvement. Gamification methods reinforced extrinsic motivation through the implementation of points, badges, and leaderboards, to strengthen individual intrinsic motivation. Continuous usage of gamification methods developed intrinsic motivation by creating an internal desire to complete tasks and diverting the source of motivation from external to internal.

According to the reported findings, a significant understanding has been gained in regards to the effect of numerous gamification elements on intrinsic motivation. The vast majority of studies (n $=53$ ) incorporated some combination of three popular gamification elements: points, badges, and 
leaderboards. Thus, the implementation, effectiveness, and feasibility of integration into the Felicity App will be assessed.

\section{Points}

A number of the included studies $(\mathrm{n}=38)$ used a points system to record user progress and growth. Much like in video games, many of these studies found that Experience Points (XP) assisted the completion of various tasks by providing participants with insight into their level of progress. Subsequent increases in engagement and level of interest in tasks often resulted in improved outcomes, such as higher, more consistent test scores and class participation. Qualitative data from semi-structured interviews found that these points systems provided encouragement to participate in learning activities. Moreover, point systems were found to be helpful in providing external validation regarding the value of one's work.

35 studies coupled the points system with a leaderboard, badges, or an external reward system. Two of the three studies that only included a point system found that the intervention on its own had no significant effect on the outcome, even though the point system encouraged motivation. Similarly, Felicity should implement a point system, rewarding users for completed tasks. These points will be assigned a weighted value, based on the kind of task completed and will be used to compete in leaderboards and acquire badges. The effects of these additional components will be assessed in the following paragraphs.

\section{Leaderboards}

The integration of leaderboards, as a gamified intervention, demonstrated an increase in student motivation $(n=32)$. Leaderboards allow students to compare their own achievements amongst peers to foster competition and social recognition. The participants in the studies attributed this gaming element to increase positive competition, subsequently increasing their motivation to take on tasks and to perform well. Qualitative data from interviews and focus groups, however, revealed that some students reported feeling less motivated to participate as a result of this added competition. This appears to be the case with students who were unable to reach a high rank on leaderboards. To address this concern many of these studies limited leaderboards to social groups and/or academic cohorts.

Acknowledgement of progress and achievements has been reported to have increased motivation in students. Whether through rankings and badges or socially by teachers and peers, participants in the studies reported that recognition increased the students' desire to complete more activities.

Felicity will reinforce positive competition and achievement recognition on an individual and user-based level by implementing leaderboards into its design. To prevent demotivation amongst users, because of the possible intensity of competition, Felicity will create an option to group users and thereby create an intimate and inclusive environment. As such, the incorporation of 
leaderboards for friend groups and academic classes seems to be the most effective to enhance the intrinsic motivation of students, as noted in Chan's study [33].

\section{Badges}

Along with point systems and leaderboards, several studies utilized digital badge systems. According to Alsawaeir [41], players who earned badges felt inner satisfaction as their status was shared and displayed publicly in the gamified environment. The study added that badges not only signal progress, but also serve as indications of past achievements. Additionally, by creating extrinsically motivating conditions through points, badges, and leaderboards, to encourage intrinsic motivation, the individual's focus gradually shifts from seeking rewards to completing tasks to fulfill internal desires.

In order to implement a badge system as effectively as possible in the Felicity app, upon acquiring specific achievements, badges will be displayed on the user's profile, which can be viewed publicly. Furthermore, it would be useful to include a feature that allows these badges to be shared on social media. Despite serving as a form of extrinsic motivation, the goal of this system is to assign value to otherwise menial tasks which may be difficult to complete. Thus, it will be useful to acknowledge and reward dedication and the completion of tasks through badges such as, "completed seven scheduled tasks" or "worked for six hours". Daily attendance badges will also be utilized to reinforce application use and promote productivity-associated behaviour, such as the completion of tasks.

\section{Strengths and Limitations}

Qualitative, quantitative, and mixed methods studies were examined for this systematic review. The mixed methods design provides a holistic view of the findings by incorporating both qualitative and quantitative data. Data were collected from a diverse pool of literature that focused on key concepts related to gamification and student intrinsic motivation. Beyond the quantitative findings, excerpts were analyzed from interviews and focus groups, which yielded a more in-depth understanding of the participants' experiences and opinions regarding gamification in education.

The systematic review includes studies from many regions within North America, Europe, and Asia. 17 studies were conducted in all countries in North America; 42 studies were conducted in Europe, encompassing the Eastern, Northern, Southern, and Western regions; 17 studies were conducted in Asia, encompassing the East, South East, and Middle East regions. Data were extracted from a variety of countries and education systems to inspect the impact of gamification on students within these areas. Studies that were not written in the English language were excluded from the systematic review which may limit the scope of the literature collection. As the Felicity app will be mostly accessible to members of these regions, measures were taken to ensure that the literature collected is representative of the target population. 
There were some challenges regarding the objectivity of the MMAT ratings during the quality appraisal process. When rating qualitative and mixed methods studies, subjective judgement was required to assess the methodological quality criterion "Is there coherence between qualitative data sources, collection, analysis and interpretation?". While the two authors responsible for quality appraisal came to an agreement as to what is considered relevant and significant, the MMAT ratings may not serve as a fully objective tool of measurement.

Another limitation of the systematic review is a lack of longitudinal studies that focused on the long-term effects of gamification on student learning. Majority of the gamified interventions introduced in the primary scientific literature were implemented for time spans ranging from a few hours to one academic semester. Data on the impact of gamification was collected immediately following the termination of the intervention. Additionally, the researchers did not follow up with the participants after time had passed since the intervention ended. As a result, there is a lack of substantial data that indicate which elements are most beneficial long-term and how certain gaming elements may influence intrinsic motivation over a long period of time.

\section{CONCLUSION}

Points, badges, and leaderboards were found to be the most effective media for using gamification to grow intrinsic motivation. 35 studies used points, leaderboards, and badges in cumulation to reinforce motivation and enhance self-efficacy. These interventions also foster positive competition and acknowledge individual achievements, which collectively inspires students to participate in and complete more activities. The level of student engagement with respect to task completion rate was also higher when utilizing gamified platforms, compared to the non-gamified condition. Therefore, gamified elements can be applied to enhance student productivity by instilling support for intrinsic motivation. The collected data provide insight for the curation of motivation-enhancing features within the Felicity App. 


\section{References}

[1] Amrai K, Motlagh SE, Zalani HA, Parhon H. The relationship between academic motivation and academic achievement students. Procedia - Soc Behav Sci. 201;15:399-402. https://doi.org/10.1016/j.sbspro.2011.03.111

[2] Organisation for Economic Co-operation and Development. In: PISA 2012 results: Ready to Learn (Volume III): Students' engagement, drive and self-beliefs. 2013. https://www.oecd-ilibrary.org/education/pisa-2012-results-ready-to-learn-volume-iii_97892 64201170-en. Accessed 7 Mar 2021.

[3] Organisation for Economic Co-operation and Development. In: PISA 2018 results (Volume III): what school life means for students' lives. 2019. https://www.oecd-ilibrary.org/education/pisa-2018-results-volume-iii_acd78851-en. Accessed 7 Mar 2021.

[4] Steinberg L, Brown BB, Dornbusch SM. Beyond the classroom. Simon and Schuster; 1997.

[5] Gnambs T, Hanfstingl B. The decline of academic motivation during adolescence: an accelerated longitudinal cohort analysis on the effect of psychological need satisfaction. Educ Psychol. 2016;36(9):1691-705. https://doi.org/10.1080/01443410.2015.1113236

[6] Deci EL, Ryan RM. Self-determination theory: a macrotheory of human motivation, development, and health. Canadian Psychology/Psychologie Canadienne. 2008;49(3):182-5. https://doi.org/10.1037/a0012801

[7] Ryan RM, Deci EL. Intrinsic and extrinsic motivations: classic definitions and new directions. Contemp Educ Psychol. 2000;25(1):54-67. https://doi.org/10.1006/ceps.1999.1020

[8] Lee JQ, McInerney DM, Liem GAD, Ortiga YP. The relationship between future goals and achievement goal orientations: an intrinsic-extrinsic motivation perspective. Contemp Educ Psychol. 2010;35(4):264-79. https://doi.org/10.1016/j.cedpsych.2010.04.004

[9] Feri R, Soemantri D, Jusuf A. The relationship between autonomous motivation and autonomy support in medical students' academic achievement. Int J Med Educ. 2016;7:417-23. https://doi.org/10.5116/ijme.5843.1097

[10] Eisenberger R, Pierce WD, Cameron J. Effects of reward on intrinsic motivation - negative, neutral, and positive: comment on Deci, Koestner, and Ryan (1999). Psychol Bull. 1999;125(6):677-91. https://doi.org/10.1037/0033-2909.125.6.677

[11] Deterding S, Sicart M, Nacke L, O’Hara K, Dixon D. Gamification: using game design elements in non-gaming contexts. In: Proceedings of the Proceedings of the 2011 Annual Conference Extended Abstracts on Human Factors in Computing Systems; 2011 May 7-12; Vancouver, Canada. New York: ACM Press; 2011 [cited 2021 Mar 7]. p. 2425-8. Available from: https://doi.org/10.1145/1979742.1979575.

[12] Seaborn K, Fels DI. Gamification in theory and action: a survey. Int J Hum-Comput Stud. 2015;74:14-31. https://doi.org/10.1016/j.ijhcs.2014.09.006 
[13] Wu Y, Kankanhalli A, Huang K-W. Gamification in fitness apps: how do leaderboards influence exercise? In: Proceedings of the 36th International Conference on Information System; 2015 Dec 13-16; Fort Worth, USA. New York: Curran Associates; 2015 [cited 2021 Mar 28]. p. 2783-94. Available from:

https://www.researchgate.net/publication/309557443_Gamification_in_Fitness_Apps_How _do_Leaderboards_influence_Exercise.

[14] TalentLMS. In: Gamification at work: the 2019 survey results. TalentLMS. 2019. https://www.talentlms.com/blog/gamification-survey-results. Accessed 13 Mar 13.

[15] TalentLMS. In: Online employee training software - TalentLMS - \#1 corporate platform. TalentLMS. https://www.talentlms.com/solutions/employee-training-software. Accessed 13 Mar 2021.

[16] Landers RN, Bauer KN, Callan RC, Armstrong MB. Psychological theory and the gamification of learning. In: Reiners T, Wood L, editors. Gamification in education and business. Springer, Cham; 2015. pp. 165-186. https://doi.org/10.1007/978-3-319-10208-5_9

[17] Sitzmann T. A meta-analytic examination of the instructional effectiveness of computer-based simulation games. Pers Psychol. 2011;64(2):489-528. https://doi.org/10.1111/j.1744-6570.2011.01190.x

[18] Dichev C, Dicheva D. Gamifying education: what is known, what is believed and what remains uncertain: a critical review. Int J Educ Technol High Educ. 2017;14(1):1-36. https://doi.org/10.1186/s41239-017-0042-5

[19] Clement J. In: Global gamification market value 2021. Statista. 2021. https://www.statista.com/statistics/608824/gamification-market-value-worldwide/. Accessed 13 Mar 2021.

[20] Robson K, Plangger K, Kietzmann JH, McCarthy I, Pitt L. Game on: engaging customers and employees through gamification. Bus Horiz. 2016;59(1):29-36. https://doi.org/10.1016/j.bushor.2015.08.002

[21] Linehan C, Kirman B, Lawson S, Chan G. Practical, appropriate, empirically-validated guidelines for designing educational games. In: Proceedings of the CHI 2011 Conference on Human Factors in Computing Systems; 2011 May 7-12; Vancouver, Canada. New York: ACM Press; 2011 [cited 2021 Mar 7]. p. 1979-88. Available from: https://doi.org/10.1145/1978942.1979229.

[22] Karimi K, Nickpayam J. Gamification from the viewpoint of motivational theory. Emerg Sci J. 2017;1(1):34. https://doi.org/10.28991/esj-2017-01114

[23] Rosas R, Nussbaum M, Cumsille P, Marianov V, Correa M, Flores P, et al. Beyond Nintendo: design and assessment of educational video games for first and second grade students. Comput Educ. 2003;40(1):71-94. https://doi.org/10.1016/S0360-1315(02)00099-4

[24] Anderson M, Jiang J. In: Teens, social media \& technology 2018. Pew Research Center. 2018. 
https://www.pewresearch.org/internet/2018/05/31/teens-social-media-technology-2018/. Accessed 13 Mar 2021.

[25] International Telecommunication Union. In: Measuring digital development: facts and figures 2020. International Telecommunication Union. 2020.

https://www.itu.int/en/ITU-D/Statistics/Documents/facts/FactsFigures2020.pdf. Accessed 13 Mar 2021.

[26] Elias H, Mustaf SMS, Roslan S, Noah SM. Motivational predictors of academic performance in end year examination. Procedia - Soc Behav Sci. 2011;29:1179-88. https://doi.org/10.1016/j.sbspro.2011.11.352

[27] Witt M, Scheiner C, Robra-bissantz S. Gamification of online idea competitions: insights from an explorative case. Paper presented at Informatik 2011 - Informatik Schafft Communities; Berlin, Germany; 2011 Oct 4-7.

[28] Schoonenboom J, Johnson RB. How to construct a mixed methods research design. KZfSS Köln Z Für Soziol Sozialpsychologie. 2017;69(2):107-31. https://doi.org/10.1007/s11577-017-0454-1.

[29] Wisdom J, Creswell JW. in: Mixed methods: integrating quantitative and qualitative data collection and analysis while studying patient-centered medical home models. Agency for Healthcare Research and Quality. 2013. https://pcmh.ahrq.gov/page/mixed-methods-integrating-quantitative-and-qualitative-data-co llection-and-analysis-while. Accessed 13 Mar 2021.

[30] Hong QN, Pluye P, Fàbregues S, Bartlett G, Boardman F, Cargo M, et al. In: Mixed methods appraisal tool (MMAT) version 2018. McGill University. 2018. http://mixedmethodsappraisaltoolpublic.pbworks.com/w/file/fetch/127916259/MMAT_201 8_criteria\%20manual_2018\%202008\%202001_ENG.pdf. Accessed 13 Mar 2021.

[31] Hong QN, Pluye P, Fàbregues S, Bartlett G, Boardman F, Cargo M, et al. Improving the content validity of the mixed methods appraisal tool: a modified e-Delphi study. J Clin Epidemiol. 2019;111:49-59. https://doi.org/10.1016/j.jclinepi.2019.03.008

[32] Facey-Shaw L, Specht M, Rosmalen P van, Brner D, Bartley-Bryan J. Educational functions and design of badge systems: a conceptual literature review. IEEE Trans Learn Technol. 2018;11(4):536-44. https://doi.org/10.1109/TLT.2017.2773508

[33] Chan G, Arya A, Orji R, Zhao Z. Motivational strategies and approaches for single and multi-player exergames: a social perspective. PeerJ Comput Sci. 2019;5. https://doi.org/10.7717/peerj-cs.230

[34] Herbert B, Charles D, Moore A, Charles T. An investigation of gamification typologies for enhancing learner motivation. In: Proceedings of the 2014 International Conference on Interactive Technologies and Games; 2014 Oct 16-17; Nottingham, UK. New York: IEEE; 2014 [cited 2021 Mar 28]. p. 71-8. Available from: https://doi.org/10.1109/iTAG.2014.17.

[35] Dicheva D, Dichev C, Agre G, Angelova G. Gamification in education: a systematic 
mapping study. J Educ Technol Soc. 2015;18(3):75-88. https://eric.ed.gov/?id=EJ1070047

[36] Mosalanejad L, Razeghi B, Ifard SA. Educational game: a fun and team based learning in psychiatric course and its effects on learning indicators. Bangladesh J Med Sci. 2018;17(4):631-7. https://doi.org/10.3329/bjms.v17i4.38328

[37] Piras L, Dellagiacoma D, Perini A, Susi A, Giorgini P, Mylopoulos J. Design thinking and acceptance requirements for designing gamified software. In: Proceedings of the 2019 13th International Conference on Research Challenges in Information Science (RCIS); 2019 May 29-31; Brussels, Belgium. New York: IEEE; 2019 [cited 2021 Mar 28]. p. 1-12. Available from: https://doi.org/10.1109/RCIS.2019.8876973.

[38] Saputro RE, Salam S, Zakaria M, Anwar T. A gamification framework to enhance students' intrinsic motivation on MOOC. Telkomnika Telecommun Comput Electron Control. 2019;17(1):170-8. https://doi.org/10.12928/TELKOMNIKA.v17i1.10090

[39] Zhang R, Cheng G, Chen X. Game-based self-regulated language learning: theoretical analysis and bibliometrics. PLoS One. 2020;15(12):e0243827. https://doi.org/10.1371/journal.pone.0243827

[40] Connolly TM, Boyle EA, MacArthur E, Hainey T, Boyle JM. A systematic literature review of empirical evidence on computer games and serious games. Comput Educ. 2012;59(2):661-86. https://doi.org/10.1016/j.compedu.2012.03.004

[41] Alsawaier RS. The effect of gamification on motivation and engagement. Int J Inf Learn Technol. 2018 Jan 1;35(1):56-79. https://doi.org/10.1108/IJILT-02-2017-0009 


\section{DECLARATIONS}

Funding: This systematic review was funded in part by a grant from The Duke of Edinburgh's International Award through the P2P program and in partnership with the federal government of Canada.

\section{Conflicts of interest/Competing interests:}

The authors declared no potential conflicts of interest with respect to the research, authorship, and/or publication of this article.

\section{Availability of data and material:}

\section{Code availability:}

$\mathrm{N} / \mathrm{A}$

\section{Authors' contributions:}

JX devised and supervised the project and secured funding acquisition. AL and HD conceptualized the review, $\mathrm{AL}, \mathrm{HD}$, and $\mathrm{SB}$ designed the protocol and search articles, $\mathrm{AL}$ and HD revised the protocol, SB and SS completed preliminary and full-text screenings, AL, HD, SA, and UN completed hand searches, AL and SA completed quality assessment and data extraction. AL created figures and computed numerical data, UN completed the data analysis, AL, HD, SA, SB, UN, and SS equally wrote the manuscript. All authors reviewed the final manuscript.

\section{Appendix 1}

\section{Database Searches}

January 4, 2021 to January 16, 2021

\begin{tabular}{|l|l|l|}
\hline Database & Search & Results \\
\hline $\begin{array}{l}\text { Institute of Electrical } \\
\text { and Electronics } \\
\text { Engineers }\end{array}$ & $\begin{array}{l}(((()((\text { Onull Text Only":Gamif*) AND "Full Text } \\
\text { Text Only":Student) NOT "Full Text Only":Econ*) AND } \\
\text { "Full Text Only":Motivat*) AND "Full Text Only":intrinsic } \\
\text { motivat*) NOT "Full Text Only": extrinsic motivat*) }\end{array}$ & 89 \\
\hline APA PsychInfo & $\begin{array}{l}\text { (Gamif*) AND (Educ*) AND (Psych*) AND (Student) NOT } \\
\text { (Econ*) OR (Motivat*) OR Self-determination theory) AND } \\
\text { (autonom*) AND (intrinsic motiv*) NOT (extrinsic } \\
\text { motivat*) }\end{array}$ & 8 \\
\hline
\end{tabular}




\begin{tabular}{|l|l|l|}
\hline ProQuest & $\begin{array}{l}\text { Gamif* AND Motiv* AND Educ* AND Psych* AND } \\
\text { (Intrinsic Motiv*) NOT (Econ*) AND (Self determination } \\
\text { theory) }\end{array}$ & 231 \\
\hline
\end{tabular}

\section{Appendix 2}

\section{Grey Literature Searches}

January 17, 2021

\begin{tabular}{|l|l|l|}
\hline Database & Search & Results \\
\hline $\begin{array}{l}\text { International Society } \\
\text { for Technology in } \\
\text { Education }\end{array}$ & Gamification AND intrinsic motivation AND student & 14 \\
\hline Edutopia.org & Gamification AND motivation in learning & \\
\hline
\end{tabular}




\section{Appendix 3}

\section{List of Excluded Studies from Quality Appraisal}

\begin{tabular}{|l|l|}
\hline Author & Article Title \\
\hline Brull S \& Finlayson S & Importance of Gamification in Increasing Learning \\
\hline Danka I & $\begin{array}{l}\text { Motivation by gamification: Adapting motivational tools of massively } \\
\text { multiplayer online role-playing games (MMORPGs) for peer-to-peer } \\
\text { assessment in connectivist massive open online courses (cMOOCs) }\end{array}$ \\
\hline Oldenhave D et al. & $\begin{array}{l}\text { Using Game Psychology in Information System Design for Sustainable } \\
\text { Behavior Changes }\end{array}$ \\
\hline Randall DL et al. & $\begin{array}{l}\text { Giving credit where credit is due: Designing open badges for a } \\
\text { technology Integration course }\end{array}$ \\
\hline Hickey DT et al. & $\begin{array}{l}\text { Badges design principles documentation project: Interim report January } \\
\text { 2014 update }\end{array}$ \\
\hline Engedal JØ & Gamification: A study of motivational affordances \\
\hline Jackson M & Gamification in education: A literature review \\
\hline Grabowski J et al. & Gamification in online education: how and why? \\
\hline Perez BG & $\begin{array}{l}\text { Applying gamification to education: A case study in an e-learning } \\
\text { environment }\end{array}$ \\
\hline Davidson S \& Candy L & $\begin{array}{l}\text { Gameful learning as a teaching/learning strategy: Best practices and } \\
\text { lessons learned }\end{array}$ \\
\hline Nicholson S & A user-centered theoretical framework for meaningful gamification \\
\hline Lee J \& Hammer J & Gamification in education: What, how, why bother? \\
\hline Molina-Carmona R \& & $\begin{array}{l}\text { Gamification and Advanced Technology to Enhance Motivation in } \\
\text { Education }\end{array}$ \\
\hline
\end{tabular}




\section{Excluded Files from Hand Searches}

\begin{tabular}{|c|c|}
\hline Author & $\underline{\text { Title }}$ \\
\hline Anderson, A et al. & Steering User Behaviour with Badges \\
\hline Bruder, $\mathrm{P}$ & Game on: Gamification in the classroom \\
\hline Clements, $\mathrm{J}$ & Gamification: Freshman English can be a game \\
\hline Farber, $\mathrm{M}$ & Beyond badges: Why gamify? \\
\hline Hamari, J et al. & Does gamification work? A literature review of empirical studies on gamification \\
\hline Foster, $\mathrm{J}$ & The promise of digital badges \\
\hline Hamari, J & Does gamification work? A literature review of empirical studies on gamification \\
\hline Keeler, A & Beyond the worksheet: Playsheets, GBL, and gamification \\
\hline Kim, Y et al & Connecting agents: Engagement and motivation in online collaboration \\
\hline Kumar, B et al & Gamification in education: Learn computer programming with fun. \\
\hline Hakulinen, $\mathrm{L}$ et al & $\begin{array}{l}\text { Empirical study on the ef-fect of achievement badges in TRAKLA2 online learning } \\
\text { environment }\end{array}$ \\
\hline Lieberman, D & What can we learn from playing interactive games \\
\hline Monterrat, B et al & A framework to adapt gamification in learning environments \\
\hline O’Byrne et al & $\begin{array}{l}\text { Digital badges recognizing, assessing, and motivating learners in and out of school } \\
\text { contexts }\end{array}$ \\
\hline Papastergiou, M & $\begin{array}{l}\text { Digital game-based learning in high school computes science education: Impact on } \\
\text { educational effectiveness and student motivation }\end{array}$ \\
\hline S. O’Donovan, et al & A case study in the gamification of a university-level games development course \\
\hline Jafari, $\mathrm{S}$ et al & $\begin{array}{l}\text { Investigating the relationship between learning style and game type in the game-based } \\
\text { learning environment }\end{array}$ \\
\hline Andrias, $R$ et al & User/Player Type in Gamification \\
\hline Haaranen, L et al & $\begin{array}{l}\text { Software Architectures for Implementing Achievement Badges - Practical } \\
\text { Experiences }\end{array}$ \\
\hline
\end{tabular}




\section{Excluded files from full text motivation}

\begin{tabular}{|c|c|}
\hline Author & Title \\
\hline Ehsan, A et.al & Performance appraisal of knowledge workers in $R \& D$ centers using gamification \\
\hline Lourdes, A & Learning Prosody in a Video Game-Based Learning Approach \\
\hline Ines, A & Gamification: methodology to engage and motivate students in the learning process \\
\hline Paz, D.P et.al & $\begin{array}{l}\text { Use of Information and communications technology in language teaching: Connecting } \\
\text { knowledges }\end{array}$ \\
\hline Demkah, M \& Bhargava, D & $\begin{array}{l}\text { Gamification in Education: A Cognitive Psychology Approach to Cooperative and Fun } \\
\text { Learning }\end{array}$ \\
\hline Bovermann, $\mathrm{K}$ et.al & $\begin{array}{l}\text { Online learning readiness and attitudes towards gaming in gamified online learning - a } \\
\text { mixed methods case study: Revista de Universidad y Sociedad del Conocimiento }\end{array}$ \\
\hline Patrick, B et.al & Game On! Students?Perceptions of Gamified Learning \\
\hline Tlili, A et.al & Personality Effects on Students' Intrinsic Motivation in a Gamified Learning Environment \\
\hline Sun, Y.A \& Chiou, M.J & $\begin{array}{l}\text { Online Platform to Evolve and Develop Motivational Theories on Manufacturing } \\
\text { Management Learning to Achieve Pandemic Curriculum Outcomes }\end{array}$ \\
\hline $\mathrm{Su}, \mathrm{C} . \mathrm{H}$ & $\begin{array}{l}\text { Exploring Sustainability Environment Educational Design and Learning Effect Evaluation } \\
\text { through Migration Theory: An Example of Environment Educational Serious Games }\end{array}$ \\
\hline Cinganotto, $\mathrm{L}$ & Gamification and virtual worlds for language learning \\
\hline Cohard, P & Evaluation of Serious Game User Experience: the Role of Emotions \\
\hline Qiu, C.S & The impact of a gamified world on medical education \\
\hline Labrador, E. \& Portero, E.V & Gamification and User eXperience for make the learning experience better \\
\hline Waweru, B.W et.al & Gamesy: How Videogames Serve as a Better Replacement for School? \\
\hline Fernandez, M.M & $\begin{array}{l}\text { MÉTODOS PEDAGÓGICOS EMERGENTES PARA UN NUEVO SIGLO ¿QUÉ HAY } \\
\text { REALMENTE DE INNOVACIÓN? }\end{array}$ \\
\hline Valero, A.F et.al & $\begin{array}{l}\text { Gamification in Physical Education: Evaluation of Impact on Motivation and Academic } \\
\text { Performance within Higher Education }\end{array}$ \\
\hline Malicki, A et.al & Gamification in nursing: a literature review \\
\hline Fleischmann, K \& Ariel, E & $\begin{array}{l}\text { Gamification in Science Education: Gamifying Learning of Microscopic Processes in the } \\
\text { Laboratory }\end{array}$ \\
\hline Fuhrmann, $\mathrm{T}$ & Motivation Centered Learning \\
\hline
\end{tabular}




\begin{tabular}{|c|c|}
\hline Gadanecz, P & The nature of positive emotions via online language learning \\
\hline Taylyn, H et.al & $\begin{array}{l}\text { From here to there! Elementary: A game-based approach to developing number sense and } \\
\text { early algebraic understanding }\end{array}$ \\
\hline Hung, H.T & $\begin{array}{l}\text { Clickers in the flipped classroom: Bring your own device (BYOD) to promote student } \\
\text { learning }\end{array}$ \\
\hline Dichev, C et.al & Towards Activity-Centered Gamification Design \\
\hline Denden, $M$ et.al & Students' learning performance in a gamified and self-determined learning environment \\
\hline Chang, J.W \& Wei, H.Y & Exploring Engaging Gamification Mechanics in Massive Online Open Courses \\
\hline Kapsalis, G.D & $\begin{array}{l}\text { Kahoot! As a Formative Assessment Tool in Foreign Language Learning: A Case Study } \\
\text { in Greek as an L2 }\end{array}$ \\
\hline Kim, $S$ & Team Organization Method Using Salary Auction Game for Sustainable Motivation \\
\hline Marczak, $\mathrm{R}$ et.al & Influence of Dissociated Mechanisms of Gamification on the Learning of Reading \\
\hline Matute, J \& Melero, I & $\begin{array}{l}\text { Game-based learning: using business simulators in the university classroom/Aprender } \\
\text { jugando: la utilización de simuladores empresariales en el aula universitaria+F190 }\end{array}$ \\
\hline Rodenburg, D & Dynamically adaptive simulation based on expertise and cognitive load \\
\hline Ndlovu, T.N \& Mhlongo, S & $\begin{array}{l}\text { An investigation into the effects of gamification on students' situational interest in a } \\
\text { learning environment }\end{array}$ \\
\hline Yousefi, B.H, \& Mirkhezri, H & $\begin{array}{l}\text { Toward A Game-based Learning Platform : A Comparative Conceptual Framework for } \\
\text { Serious Games }\end{array}$ \\
\hline Moody, S et.al & Vocabulary Instruction: A Critical Analysis of Theories, Research, and Practice \\
\hline Tal, I et.al & $\begin{array}{l}\text { Mulsemedia in Telecommunication and Networking Education: A Novel Teaching } \\
\text { Approach that Improves the Learning Process }\end{array}$ \\
\hline Zamorano L.R et.al & Gamified crowdsourcing in higher education: A theoretical framework and a case study \\
\hline Oberdorfer, S \& Latoschik, M.E & $\begin{array}{l}\text { Knowledge Encoding in Game Mechanics: Transfer-Oriented Knowledge Learning in } \\
\text { Desktop-3D and VR }\end{array}$ \\
\hline Kamunya $\mathrm{S}$ et.al & A Gamification Model For E-Learning Platforms \\
\hline Ohn, M.H et.al & Gamified Online Active Learning Theory \\
\hline Santos, T.C \& Parizi, R.B & Gamification and Project-Based Learning as Software Quality Teaching Methodologies \\
\hline Dzerdz, M.P & Gamifying Online Tests to Promote Retrieval-Based Learning \\
\hline Mayer, R.E & Theory: Applying Cognitive Science to Games for Learning \\
\hline
\end{tabular}




\begin{tabular}{|c|c|}
\hline Rist, $\mathrm{T} \&$ Masoodian, $\mathrm{M}$ & $\begin{array}{l}\text { Promoting Sustainable Energy Consumption Behavior through Interactive Data } \\
\text { Visualizations }\end{array}$ \\
\hline Sanchez, S.P et.al & $\begin{array}{l}\text { Gamification as a Methodological Complement to Flipped Learning-An Incident Factor } \\
\text { in Learning Improvement }\end{array}$ \\
\hline Smiderle, $\mathrm{R}$ et.al & $\begin{array}{l}\text { The impact of gamification on students' learning, engagement and behavior based on } \\
\text { their personality traits }\end{array}$ \\
\hline Smith, $\mathrm{T}$ & $\begin{array}{l}\text { Gamified modules for an introductory statistics course and their impact on attitudes and } \\
\text { learning }\end{array}$ \\
\hline Jarvis, $\mathrm{K}$ & Using Gamification to Increase Engagement During Hybrid Learning \\
\hline Willis, J & Matching Edtech Products With Neurological Learning Goals \\
\hline Moler, A & Does Our Natural Affinity for Games Have a Place in the Classroom? \\
\hline Jain, $\mathrm{R}$ & Can stress help students? \\
\hline Willis, J & Strategies to Prevent the Neurotoxic Impact of School Stress \\
\hline Fodor, Z & $\begin{array}{l}\text { 'Gamified' Technology Supported Project Based Learning + Student Habits of Mind } \\
\text { Leveraging Aspects of Games Like MinecraftEdu in Order To Achieve Something } \\
\text { Beyond Traditional Project Based Learning. }\end{array}$ \\
\hline
\end{tabular}




\section{Appendix 4}

\section{Study Characteristics}

\begin{tabular}{|c|c|c|c|c|c|c|}
\hline $\begin{array}{l}\text { Author, date, title of } \\
\text { study }\end{array}$ & Country & $\begin{array}{l}\text { Study design, } \\
\text { duration, and } \\
\text { participants }\end{array}$ & Type of data & $\begin{array}{l}\text { Gamification } \\
\text { elements }\end{array}$ & Outcome & $\begin{array}{l}\text { Quality: } \\
\text { design/score }\end{array}$ \\
\hline $\begin{array}{l}\text { Hernandez-Fernandez, } \\
\text { 2020, Is Classroom } \\
\text { Gamification Opposed to } \\
\text { Performance? }\end{array}$ & Spain & $\begin{array}{l}\text { Qualitative; } 175 \mathrm{~h} \\
\text { classroom hours and } \\
133 \mathrm{~h} \text { on virtual } \\
\text { platform; } 151 \text { masters } \\
\text { students across } 3 \\
\text { academic years }\end{array}$ & $\begin{array}{l}\text { Longitudinal case-study; } \\
\text { Final mark in the course } \\
\text { (obtained from various } \\
\text { assessments/activities), } \\
\text { attendance, surveys (on } \\
\text { subject and teachers), } \\
\text { gamified points }\end{array}$ & Points & $\begin{array}{l}\text { Negative correlation between the scores of } \\
\text { the evaluations and the marks obtained in } \\
\text { the activities of gamification. The group } \\
\text { less involved in the gamification obtained } \\
\text { better academic results. Gamification } \\
\text { improved motivation. }\end{array}$ & $1 / * * * *$ \\
\hline $\begin{array}{l}\text { Abdollahzade, } 2018, \\
\text { Investigating the } \\
\text { Relationship between } \\
\text { Player Types and } \\
\text { Learning Styles in } \\
\text { Gamification Design }\end{array}$ & Iran & $\begin{array}{l}\text { Quantitative } \\
\text { Descriptive; } 121 \\
\text { university students }\end{array}$ & $\begin{array}{l}\text { Questionnaire on learner } \\
\text { styles }(\mathrm{n}=44) \text {; questionnaire } \\
\text { to measure type of player } \\
(\mathrm{n}=24)\end{array}$ & N/A & $\begin{array}{l}\text { Confirmed relationships between specific } \\
\text { player types and learning styles (e.g. } \\
\text { socializer player and active learning style) } \\
\text { suggesting that certain players respond } \\
\text { best to certain forms of learning (like } \\
\text { e-learning). }\end{array}$ & $4 / * * * *$ \\
\hline $\begin{array}{l}\text { Alsawaier, } 2018 \text {, The } \\
\text { effect of gamification on } \\
\text { motivation and } \\
\text { engagement }\end{array}$ & USA & $\begin{array}{l}\text { Qualitative; first part } \\
\text { of research trilogy }\end{array}$ & $\begin{array}{l}\text { Critical analysis of } \\
\text { literature on gamification }\end{array}$ & $\begin{array}{l}\text { Avatars, quests } \\
\text { and challenges, } \\
\text { badges, points and } \\
\text { levels. }\end{array}$ & $\begin{array}{l}\text { Gamification uses various theories. There } \\
\text { are different player types. gamification } \\
\text { features include avatars, quests and } \\
\text { challenges, badges, points and level. } \\
\text { Gamification is connected to motivation, } \\
\text { engagement, and fun. More research must } \\
\text { be conducted on the topic. }\end{array}$ & $1 / *$ \\
\hline $\begin{array}{l}\text { Alvaro-Tordesillas, } 2020 \text {, } \\
\text { Gamification experience } \\
\text { in the subject of } \\
\text { descriptive geometry for } \\
\text { architecture }\end{array}$ & Spain & $\begin{array}{l}\text { Quantitative } \\
\text { non-randomized; } \\
\text { students aged } 18-19 \\
\text { years of age }(\mathrm{n}=321) \\
\text { throughout } 6 \text { semesters }\end{array}$ & $\begin{array}{l}\text { Academic results; surveys } \\
\text { on student perception of the } \\
\text { subject }\end{array}$ & $\begin{array}{l}\text { Points, badges, } \\
\text { and leaderboards. }\end{array}$ & $\begin{array}{l}\text { The implementation of gamification } \\
\text { improved the perception and experience } \\
\text { of the university students of the subject of } \\
\text { Descriptive Geometry, as well as the } \\
\text { development of the professor. }\end{array}$ & $3 / * * *$ \\
\hline $\begin{array}{l}\text { Mora, 2018, Effect of } \\
\text { personalized gameful } \\
\text { design on student } \\
\text { engagement }\end{array}$ & Spain & $\begin{array}{l}\text { Quantitative } \\
\text { Descriptive; } 81 \\
\text { university students for } \\
20 \text { school weeks (14 } \\
\text { gameful weeks) }\end{array}$ & $\begin{array}{l}\text { Trello user logs, practices, } \\
\text { and a survey to measure } \\
\text { student motivation to solve } \\
\text { non-evaluative activities }\end{array}$ & $\begin{array}{l}\text { Points and } \\
\text { rewards. }\end{array}$ & $\begin{array}{l}\text { Personalized gamified learning works } \\
\text { better regarding the behavioral and } \\
\text { emotional engagement of the students } \\
\text { with the course, but there weren't } \\
\text { significant results on some characteristics. }\end{array}$ & $4 / * * *$ \\
\hline $\begin{array}{l}\text { Aşılksoy, 2018, The } \\
\text { effects of the gamified } \\
\text { flipped classroom } \\
\text { environment (GFCE) on } \\
\text { students' motivation, } \\
\text { learning achievements } \\
\text { and perception in a } \\
\text { physics course }\end{array}$ & Cyprus & $\begin{array}{l}\text { Quantitative } \\
\text { randomized controlled } \\
\text { trials; } 61 \\
\text { undergraduate students } \\
\text { for } 8 \text { school weeks in a } \\
\text { physics course }\end{array}$ & $\begin{array}{l}\text { Physics motivation } \\
\text { questionnaire, } \\
\text { electromagnetism } \\
\text { achievement test and semi } \\
\text { structured interviews }\end{array}$ & $\begin{array}{l}\text { Points, badges, } \\
\text { and leaderboards. }\end{array}$ & $\begin{array}{l}\text { Gamified flipped classroom students had a } \\
\text { significantly increased motivation and } \\
\text { students' opinions on the gamified } \\
\text { classroom environment were positive. }\end{array}$ & $2 / * * *$ \\
\hline $\begin{array}{l}\text { Hakulinin, 2014, The } \\
\text { Effect of Gamification on } \\
\text { Students with Different } \\
\text { Achievement Goal } \\
\text { Orientations }\end{array}$ & Finland & $\begin{array}{l}\text { Quantitative } \\
\text { Non-Randomized; } \\
\text { university students in a } \\
\text { Data Structures and } \\
\text { Algorithms course } \\
\text { (N=278) for } 1 \\
\text { semester (half of } \\
\text { which was gamified) }\end{array}$ & $\begin{array}{l}\text { A pre-test and post-test was } \\
\text { used to measure differences } \\
\text { in the prior knowledge; goal } \\
\text { orientation survey; course } \\
\text { feedback questionnaire on } \\
\text { badges; first half vs second } \\
\text { half performance }\end{array}$ & Points and badges. & $\begin{array}{l}\text { No significant differences in the behavior } \\
\text { of the different goal orientation groups } \\
\text { regarding badges. Students who reported } \\
\text { high motivation towards badges had } \\
\text { higher mastery-intrinsic, mastery-extrinsic } \\
\text { and performance-approach orientation, } \\
\text { and lower avoidance-orientation. }\end{array}$ & $3 / * * * *$ \\
\hline Facey-Shaw, 2018, & Jamaica and & Qualitative; literature & Literature review regarding & Badges & The three core design dimensions found & $1 / * * * * *$ \\
\hline
\end{tabular}




\begin{tabular}{|c|c|c|c|c|c|c|}
\hline $\begin{array}{l}\text { Educational Functions } \\
\text { and Design of Badge } \\
\text { Systems: A Conceptual } \\
\text { Literature Review }\end{array}$ & Netherlands & $\begin{array}{l}(\mathrm{n}=63) \text { from electronic } \\
\text { databases }(\mathrm{n}=7) \\
\text { between } 2010-2016\end{array}$ & specific gamification tools & & $\begin{array}{l}\text { were the specific function of badges, the } \\
\text { structure of badge systems and the } \\
\text { different types of interactions with } \\
\text { badges. Results are mixed, but many } \\
\text { report positive results concerning } \\
\text { aesthetics. Overall the potential of badges } \\
\text { for learning in various disciplines and } \\
\text { across all educational levels, from } \\
\text { elementary to post-secondary seems to be } \\
\text { confirmed. }\end{array}$ & \\
\hline $\begin{array}{l}\text { Breatman, 2019, Games } \\
\text { in Learning: Shedding } \\
\text { Light on a Problematic } \\
\text { Taxonomy }\end{array}$ & USA & $\begin{array}{l}\text { Qualitative; } 50 \\
\text { definitions were } \\
\text { sourced through } \\
\text { examining original } \\
\text { source literature }\end{array}$ & $\begin{array}{l}\text { The literature was surveyed } \\
\text { for the definitions terms } \\
\text { relating to this paradigm } \\
\text { through both a survey of the } \\
\text { literature and a novel } \\
\text { variant of sorting activity }\end{array}$ & N/A & $\begin{array}{l}\text { Individual item definitions do not } \\
\text { semantically cluster together by } \\
\text { corresponding term (suggests lack of } \\
\text { clarity and consensus). Through both the } \\
\text { survey of the literature and the card sort } \\
\text { analysis, the disjointed state of the current } \\
\text { disciplines of study becomes rapidly } \\
\text { apparent. }\end{array}$ & $1 / * * * *$ \\
\hline $\begin{array}{l}\text { Chan, 2019, Motivational } \\
\text { strategies and approaches } \\
\text { for single and } \\
\text { multi-player exergames: } \\
\text { a social perspective }\end{array}$ & Canada & $\begin{array}{l}\text { Qualitative; identified } \\
30 \text { articles from } 5 \\
\text { electronic databases }\end{array}$ & $\begin{array}{l}\text { Literature review (snowball } \\
\text { method) }\end{array}$ & Social interaction. & $\begin{array}{l}\text { Exergames are effective at motivating } \\
\text { people to participate in exercise, but not } \\
\text { long-term. Gamification uses } \\
\text { self-determination theory. Players are } \\
\text { motivated by social interaction, } \\
\text { competition, and cooperation. }\end{array}$ & $1 / * * * * *$ \\
\hline $\begin{array}{l}\text { Mi, 2018, A } \\
\text { Gamification Technique } \\
\text { for Motivating Students } \\
\text { to Learn Code } \\
\text { Readability in Software } \\
\text { Engineering }\end{array}$ & Hong Kong & $\begin{array}{l}\text { Quantitative } \\
\text { randomized controlled } \\
\text { trials; } 14 \text { days } \\
\text { involving } \\
\text { undergraduate students } \\
(\mathrm{n}=161) \text {; control } \\
(\mathrm{n}=81)\end{array}$ & $\begin{array}{l}\text { Post-experiment } \\
\text { questionnaire collecting } \\
\text { student feedback on } \\
\text { perceived ease of use, } \\
\text { perceived usefulness, } \\
\text { attitude toward game design } \\
\text { elements, and user } \\
\text { satisfaction }\end{array}$ & $\begin{array}{l}\text { Points, badges, } \\
\text { and leaderboards. }\end{array}$ & $\begin{array}{l}\text { Points and leaderboards are more effective } \\
\text { than badges in motivating students to } \\
\text { participate. Gaming techniques weren't as } \\
\text { attractive to students. Gaming technique } \\
\text { was easy to use. }\end{array}$ & $2 / * * *$ \\
\hline $\begin{array}{l}\text { Herbert, 2014, An } \\
\text { Investigation of } \\
\text { Gamification Typologies } \\
\text { for Enhancing Learner } \\
\text { Motivation }\end{array}$ & $\begin{array}{l}\text { Northern } \\
\text { Ireland }\end{array}$ & $\begin{array}{l}\text { Mixed Methods; two } \\
\text { twelve week long } \\
\text { computing modules } \\
\text { with university } \\
\text { students ( } \mathrm{n}=93 \text { ) }\end{array}$ & $\begin{array}{l}\text { Questionnaire to establish } \\
\text { their gamification learning } \\
\text { profile and developed a } \\
\text { decision tree to track } \\
\text { relationship with intrinsic } \\
\text { and extrinsic motivation; } \\
\text { tracked learner movement } \\
\text { and number of resources } \\
\text { used; measured learner } \\
\text { performance average }\end{array}$ & $\begin{array}{l}\text { Points, badges, } \\
\text { visible status, } \\
\text { unlockable } \\
\text { content, } \\
\text { customization, } \\
\text { levels, and } \\
\text { leaderboards. }\end{array}$ & $\begin{array}{l}\text { Good relationship between clusters of } \\
\text { learner gamification type and learner } \\
\text { interactive behavior within the gamified } \\
\text { technique. behavior of each gamification } \\
\text { type was consistent between two separate } \\
\text { learning modules. }\end{array}$ & $5 / * * * * *$ \\
\hline $\begin{array}{l}\text { Chasanidou, 2018, } \\
\text { Design for Motivation: } \\
\text { Evaluation of a Design } \\
\text { Tool }\end{array}$ & Norway & $\begin{array}{l}\text { Qualitative; one pilot } \\
\text { study and six } \\
\text { workshops with } \\
\text { participants with } \\
\text { multidisciplinary } \\
\text { backgrounds }(\mathrm{n}=32)\end{array}$ & $\begin{array}{l}\text { A pre-questionnaire (open } \\
\text { questions measured with } \\
\text { likert scale), observations } \\
\text { with field notes and } \\
\text { video-recordings during the } \\
\text { workshop, and a } \\
\text { post-questionnaire (about } \\
\text { experience and satisfaction) } \\
\text { and audio-recorded } \\
\text { sem-structured interviews } \\
\text { after the workshop }\end{array}$ & Cards & $\begin{array}{l}\text { The results indicate that the design } \\
\text { process of creating motivational } \\
\text { innovation platforms is supported by the } \\
\text { features of the DEMO tool. }\end{array}$ & $1 / * * * *$ \\
\hline $\begin{array}{l}\text { Clément, } 2020, \\
\text { Prospective study on a } \\
\text { fast-track training in } \\
\text { psychiatry for medical }\end{array}$ & France & $\begin{array}{l}\text { Quantitative } \\
\text { Descriptive; third-year } \\
\text { medical school } \\
\text { students ( } \mathrm{n}=166 \text { ) used }\end{array}$ & $\begin{array}{l}\text { Pre- and post-evaluation of } \\
\text { knowledge }(n=20) \text { and a } \\
\text { satisfaction survey }(n=8)\end{array}$ & N/A & $\begin{array}{l}\text { The Psychiatric Hat Game improved } \\
\text { knowledge of psychiatric semiology in } \\
\text { medical students and was enjoyable. }\end{array}$ & $4 / * * * *$ \\
\hline
\end{tabular}




\begin{tabular}{|c|c|c|c|c|c|c|}
\hline $\begin{array}{l}\text { students: the psychiatric } \\
\text { hat game }\end{array}$ & & $\begin{array}{l}\text { the "Psychiatric Hat } \\
\text { Game" for four } \\
\text { months }\end{array}$ & & & & \\
\hline $\begin{array}{l}\text { Cruz, 2014, Too cool for } \\
\text { school?: The effects of } \\
\text { gamification in an } \\
\text { advanced } \\
\text { interdisciplinary course }\end{array}$ & USA & $\begin{array}{l}\text { Qualitative; one } \\
\text { semester long; } \\
\text { undergraduate students } \\
(\mathrm{n}=43)\end{array}$ & $\begin{array}{l}\text { A survey regarding their } \\
\text { perceptions of learning } \\
\text { through gamification }(\mathrm{n}=2) \text {; } \\
\text { end-of-semester review } \\
\text { activity }\end{array}$ & $\begin{array}{l}\text { Badges, points, } \\
\text { and prizes. }\end{array}$ & $\begin{array}{l}\text { Mixed results from survey regarding } \\
\text { effect of gamification on motivation to } \\
\text { participate. many students participated } \\
\text { with the games and achieved many points. } \\
\text { Few students didn't engage with the } \\
\text { gamified elements but still performed } \\
\text { well. Under-performing students enjoyed } \\
\text { gamification. }\end{array}$ & $1 / * * *$ \\
\hline $\begin{array}{l}\text { De Troyer, 2020, Playful } \\
\text { Learning with a } \\
\text { Location-Based Digital } \\
\text { Card Environment: A } \\
\text { Promising Tool for } \\
\text { Informal, Non-Formal, } \\
\text { and Formal Learning }\end{array}$ & Belgium & $\begin{array}{l}\text { Qualitative; } \\
\text { "youngsters" } \\
\text { ( } \mathrm{n}=\text { undefined) from } 11 \\
\text { organizations for } \\
\text { individual interview } \\
\text { sessions; animators } \\
\text { aged } 16-25 \text { ( } \mathrm{n}=20 \text { ) in } \\
\text { first evaluation of } \\
\text { phase } 2 \text {; animators } \\
\text { aged } 18 \text { and older } \\
(\mathrm{n}=18 \text { ) in the second } \\
\text { evaluation of phase } 2 \text {; } \\
\text { participants aged } \\
14-15 \text { ( } \mathrm{n}=6 \text { ) in first } \\
\text { evaluation of phase } 3 \\
\text { participated in a city } \\
\text { game (2h); students in } \\
\text { the second evaluation } \\
\text { of phase } 3 \text { ( } \mathrm{n}=7 \text { ) were } \\
\text { in a five day long } \\
\text { camp }\end{array}$ & $\begin{array}{l}\text { Literature review; } \\
\text { evaluation of proposed } \\
\text { design; Interviews for } \\
\text { initial evaluation of } \\
\text { application; questionnaire } \\
\text { on experience and } \\
\text { application for phases } 2 \text { and } \\
3\end{array}$ & $\begin{array}{l}\text { Points and } \\
\text { rewards. }\end{array}$ & $\begin{array}{l}\text { Feedback for initial phase was positive. } \\
\text { the application can be used for team } \\
\text { building activities, for information } \\
\text { providing, and for non-formal learning } \\
\text { activities, as well as in the context of } \\
\text { regular education in an engaging manner. }\end{array}$ & $1 / * * * *$ \\
\hline $\begin{array}{l}\text { Dichev, 2017, Gamifying } \\
\text { education: what is } \\
\text { known, what is believed } \\
\text { and what remains } \\
\text { uncertain: a critical } \\
\text { review }\end{array}$ & USA & $\begin{array}{l}\text { Qualitative; empirical } \\
\text { research studies } \\
(\mathrm{n}=51) \text { and theoretical } \\
\text { papers }(\mathrm{n}=11)\end{array}$ & $\begin{array}{l}\text { Literature review using } \\
\text { online databases }\end{array}$ & $\begin{array}{l}\text { Points, badges, } \\
\text { levels, } \\
\text { leaderboards and } \\
\text { progress bars. }\end{array}$ & $\begin{array}{l}\text { Research on gamification is diverse with } \\
\text { most papers focusing on empirical studies } \\
\text { rather than theory. Majority of the target } \\
\text { demographic is college students. Large } \\
\text { focus on badges, points, and leaderboards. } \\
\text { Not enough research on long-term effects } \\
\text { and on educational context. }\end{array}$ & $1 / * * * * *$ \\
\hline $\begin{array}{l}\text { Dicheva, 2015, } \\
\text { Gamification in } \\
\text { Education: A Systematic } \\
\text { Mapping Study }\end{array}$ & $\begin{array}{l}\text { USA and } \\
\text { Bulgaria }\end{array}$ & $\begin{array}{l}\text { Qualitative; empirical } \\
\text { studies }(\mathrm{n}=34) \\
\text { between } 2010-2014 \\
\text { from scientific } \\
\text { databases }(\mathrm{n}=7)\end{array}$ & $\begin{array}{l}\text { Systematic mapping study; } \\
\text { frameworks, patterns, } \\
\text { educational contexts, and } \\
\text { configurations of used } \\
\text { game elements collected }\end{array}$ & $\begin{array}{l}\text { Points, badges, } \\
\text { levels, progress } \\
\text { bars, leaderboards, } \\
\text { virtual currency, } \\
\text { and avatars. }\end{array}$ & $\begin{array}{l}\text { Most reviewed papers show promising } \\
\text { results. majority describe only some game } \\
\text { mechanisms and dynamics and re-iterate } \\
\text { their possible use in educational context, } \\
\text { while true empirical research on the } \\
\text { effectiveness of incorporating game } \\
\text { elements in learning environments is still } \\
\text { scarce. }\end{array}$ & $1 / * * * * *$ \\
\hline $\begin{array}{l}\text { Doney, 2019, Research } \\
\text { into effective } \\
\text { gamification features to } \\
\text { inform e-learning design: } \\
\text { Association for Learning } \\
\text { Technology Journal }\end{array}$ & $\begin{array}{l}\text { United } \\
\text { Kingdom }\end{array}$ & $\begin{array}{l}\text { Qualitative; case } \\
\text { studies }(n=41) \text { by } \\
\text { searching various } \\
\text { journals }\end{array}$ & $\begin{array}{l}\text { Data from case studies } \\
\text { categorized from } 7 \\
\text { headings }\end{array}$ & $\begin{array}{l}\text {, challenge, } \\
\text { control, feedback, } \\
\text { interaction, } \\
\text { representation, } \\
\text { rules and goals, } \\
\text { and reflection. }\end{array}$ & $\begin{array}{l}\text { There are a number of gamification } \\
\text { approaches that may be effective when } \\
\text { designing e-learning activities for adult } \\
\text { learners. Effective learning relies on what } \\
\text { happens beyond the gamification medium. }\end{array}$ & $1 / * * *$ \\
\hline $\begin{array}{l}\text { Chong, 2019, Benefits } \\
\text { and challenges with } \\
\text { gamified multi-media } \\
\text { physiotherapy case }\end{array}$ & Hong Kong & $\begin{array}{l}\text { Mixed methods; } \\
\text { year-3 students } \\
(\mathrm{n}=100) \text { in a } \\
\text { Neurological }\end{array}$ & $\begin{array}{l}\text { Interviews with focus } \\
\text { group; survey }(\mathrm{n}=12) \text { on } \\
\text { perception and satisfaction } \\
\text { on the virtual patient cases }\end{array}$ & $\begin{array}{l}\text { Narration } \\
\text { storytelling, } \\
\text { points, } \\
\text { leaderboards, }\end{array}$ & $\begin{array}{l}\text { Most students found the gamification in } \\
\text { class to be useful, enjoyable, and } \\
\text { improved motivation. Leaderboards } \\
\text { motivated the students through }\end{array}$ & $5 / * *$ \\
\hline
\end{tabular}




\begin{tabular}{|c|c|c|c|c|c|c|}
\hline $\begin{array}{l}\text { studies: a mixed method } \\
\text { study }\end{array}$ & & $\begin{array}{l}\text { Physiotherapy course } \\
\text { for } 1 \text { month; } 6 \\
\text { gamified tutorial } \\
\text { sessions; focus group } \\
\text { for feedback }(\mathrm{n}=12)\end{array}$ & & $\begin{array}{l}\text { rewards, and } \\
\text { feedback. }\end{array}$ & $\begin{array}{l}\text { visualisation of progress. Feedback on } \\
\text { performance and progress enhanced } \\
\text { self-efficacy. Team dynamics need to be } \\
\text { fostered in order to achieve the optimal } \\
\text { benefits of social interactions. }\end{array}$ & \\
\hline $\begin{array}{l}\text { Moreira, 2020, Teaching } \\
\text { and learning Modelling } \\
\text { and Specification based } \\
\text { on gamification }\end{array}$ & $\begin{array}{l}\text { Portugal and } \\
\text { Spain }\end{array}$ & $\begin{array}{l}\text { Qualitative; method } \\
\text { proposal }\end{array}$ & Literature review & $\begin{array}{l}\text { Levels, } \\
\text { leaderboards } \\
\text { (Ranking Block), } \\
\text { rewards } \\
\text { (experience points } \\
\text { (XP reward), } \\
\text { Badges and } \\
\text { Coins), Progress } \\
\text { bar and content } \\
\text { locking. }\end{array}$ & $\begin{array}{l}\text { A proposal to use gamification as a } \\
\text { teaching-learning methodology which } \\
\text { aims to increase student involvement and } \\
\text { motivation. Uses leaderboards, badges, } \\
\text { coins, progress bars and a blocking } \\
\text { system. }\end{array}$ & $1 / *$ \\
\hline $\begin{array}{l}\text { Ting, 2019, Active } \\
\text { Learning via } \\
\text { Problem-Based } \\
\text { Collaborative Games in a } \\
\text { Large Mathematics } \\
\text { University Course in } \\
\text { Hong Kong }\end{array}$ & Hong Kong & $\begin{array}{l}\text { Quantitative } \\
\text { Descriptive; 13-week } \\
\text { Applied Mathematics } \\
\text { course with } \\
\text { undergraduate students } \\
(\mathrm{n}=1017)\end{array}$ & $\begin{array}{l}\text { Pre and Post Concept and } \\
\text { Midterm Tests }(\mathrm{n}=20) \text {; } \\
\text { survey on perception of } \\
\text { active learning in class }\end{array}$ & $\begin{array}{l}\text { Points, } \\
\text { leaderboards. }\end{array}$ & $\begin{array}{l}\text { Students who perceived they were more } \\
\text { actively engaged or spent more time in } \\
\text { active learning performed better in the } \\
\text { post test. Students' perceptions of time } \\
\text { spent in active learning is a significant } \\
\text { predictor of their level of conceptual } \\
\text { understanding of differential calculus. } \\
\text { Students' perceptions of their level of } \\
\text { active engagement is a significant } \\
\text { predictor of their academic performance. }\end{array}$ & $4 / * * * *$ \\
\hline $\begin{array}{l}\text { Isanova, 2019, Towards a } \\
\text { justified choice of } \\
\text { gamification framework } \\
\text { when building an } \\
\text { educational application }\end{array}$ & Bulgaria & $\begin{array}{l}\text { Qualitative; analysis of } \\
\text { recent frameworks }\end{array}$ & $\begin{array}{l}\text { Literature review; } \\
\text { framework developed to } \\
\text { record how studies meet } \\
\text { various criteria }\end{array}$ & N/A & $\begin{array}{l}\text { Provided a theoretical framework for } \\
\text { gamification. levels, rewards, points, } \\
\text { hints, badges, challenges, goal setting, } \\
\text { progress/story, time frame, and immediate } \\
\text { feedback are useful gaming elements. }\end{array}$ & $1 / * * * *$ \\
\hline $\begin{array}{l}\text { Romero-Rodriguez, } \\
\text { 2019, Gamification in } \\
\text { MOOCs: Engagement } \\
\text { Application Test in } \\
\text { Energy Sustainability } \\
\text { Courses }\end{array}$ & Mexico & $\begin{array}{l}\text { Mixed methods; } \\
\text { quantified findings of } \\
\text { various studies; } \\
\text { research methods not } \\
\text { defined }\end{array}$ & $\begin{array}{l}\text { Literature review and } \\
\text { analysis; studies extracted } \\
\text { for features like simplicity, } \\
\text { progress, feedback, etc. }\end{array}$ & $\begin{array}{l}\text { Rewards in the } \\
\text { position charts, } \\
\text { medals, badges, } \\
\text { and points }\end{array}$ & $\begin{array}{l}\text { The degree of student engagement with } \\
\text { respect to the completion rate of activities } \\
\text { was higher in the gamified platform than } \\
\text { in the traditional design. Applying } \\
\text { gamification strategies in MOOCs } \\
\text { achieves a higher level of engagement and } \\
\text { student motivation. }\end{array}$ & $5 / * *$ \\
\hline
\end{tabular}

\begin{tabular}{|c|c|c|c|c|c|c|}
\hline $\begin{array}{l}\text { Brayshaw, 2016, Using } \\
\text { motivation derived from } \\
\text { computer gaming in the } \\
\text { context of computer } \\
\text { based instruction }\end{array}$ & $\begin{array}{l}\text { United } \\
\text { Kingdom }\end{array}$ & $\begin{array}{l}\text { Qualitative; methods } \\
\text { not well developed }\end{array}$ & $\begin{array}{l}\text { Literature review; makes no } \\
\text { mention of extracted data }\end{array}$ & N/A & $\begin{array}{l}\text { In order to motivate, desirable properties } \\
\text { include understanding and using competence, } \\
\text { autonomy and relatedness alongside rich, } \\
\text { immersive interactions, levels of achievement } \\
\text { through appropriate feedback and the } \\
\text { movement to higher levels reflecting and } \\
\text { rewarding this, user ownership of their } \\
\text { learning, and the importance of learning as a } \\
\text { social endeavour. }\end{array}$ & $1 / * *$ \\
\hline $\begin{array}{l}\text { Hammerschall, 2019, A } \\
\text { Gamification } \\
\text { Framework for } \\
\text { Long-Term Engagement } \\
\text { in Education Based on } \\
\text { Self Determination } \\
\text { Theory and the } \\
\text { Transtheoretical Model } \\
\text { of Change }\end{array}$ & Germany & $\begin{array}{l}\text { Qualitative; discussion } \\
\text { of theory and proof of } \\
\text { concept }\end{array}$ & Literature review & N/A & $\begin{array}{l}\text { A proposed framework is based on outcomes } \\
\text { from motivational (SDT, CET) and behavior } \\
\text { change (TTM) theories. }\end{array}$ & $1 / * * * *$ \\
\hline
\end{tabular}




\begin{tabular}{|c|c|c|c|c|c|c|}
\hline $\begin{array}{l}\text { Mystakidis, 2019, Enter } \\
\text { the Serious E-scape } \\
\text { Room: A Cost-Effective } \\
\text { Serious Game Model for } \\
\text { Deep and Meaningful } \\
\text { E-learning }\end{array}$ & USA & $\begin{array}{l}\text { Mixed methods; high } \\
\text { school students }(n=148) \\
\text { played a serious } \\
\text { E-scape room game for } \\
\text { two months }\end{array}$ & $\begin{array}{l}\text { Pre-test assessment }(\mathrm{n}=12) \\
\text { on game content and } \\
\text { outcomes; post-test }(\mathrm{n}=21) \\
\text { on same assessment as well } \\
\text { as evaluations on the game }\end{array}$ & $\begin{array}{l}\text { Points, badges, } \\
\text { challenges. }\end{array}$ & $\begin{array}{l}\text { Performance increase and high overall } \\
\text { satisfaction following E-scape room. The game } \\
\text { has been received enthusiastically by students, } \\
\text { it increased their motivation and helped them } \\
\text { build a deeper understanding of the learned } \\
\text { concepts. }\end{array}$ & $5 / *$ \\
\hline $\begin{array}{l}\text { Johnson-Glenberg, } 2017 \text {, } \\
\text { Embodied science and } \\
\text { mixed reality: How } \\
\text { gesture and motion } \\
\text { capture affect physics } \\
\text { education: Principles and } \\
\text { Implications }\end{array}$ & USA & $\begin{array}{l}\text { Quantitative } \\
\text { randomized controlled } \\
\text { trial; physics lesson ( } 1 \\
\text { h) with undergraduate } \\
\text { students }(n=166)\end{array}$ & $\begin{array}{l}\text { Content knowledge pre-test } \\
\text { and post-test ( } \mathrm{n}=34 \\
\text { multiple choice for } \\
\text { computer version, } \mathrm{n}=8 \text { for } \\
\text { gesture-based version), and } \\
\text { an engagement survey } \\
\text { ( } \mathrm{n}=5 \text { ) on the activity and } \\
\text { participants ranked the } \\
\text { games based on preference } \\
(\mathrm{n}=7)\end{array}$ & $\begin{array}{l}\text { Narrative } \\
\text { storytelling and } \\
\text { points. }\end{array}$ & $\begin{array}{l}\text { The predicted differences in engagement and } \\
\text { learning for the condition with the graphically } \\
\text { rich story narrative were not supported. } \\
\text { Hypothesized that a narrative effect for } \\
\text { motivation and learning may be difficult to } \\
\text { uncover in a lab experiment where participants } \\
\text { are primarily motivated by course credit. }\end{array}$ & $2 / * * *$ \\
\hline $\begin{array}{l}\text { Kermek, } 2016 \text {, } \\
\text { Preparation of a hybrid } \\
\text { e-learning course for } \\
\text { gamification }\end{array}$ & Croatia & $\begin{array}{l}\text { Mixed methods; } \\
\text { students in a learning } \\
\text { management systems } \\
\text { course for one semester }\end{array}$ & $\begin{array}{l}\text { Literature review for } \\
\text { creation of course; } \\
\text { self-assessment test scores } \\
\text { and homework score }\end{array}$ & $\begin{array}{l}\text { Points, levels, } \\
\text { leaderboards, } \\
\text { badges, } \\
\text { challenges/quests, } \\
\text { onboarding, and } \\
\text { social engagement } \\
\text { loops. }\end{array}$ & $\begin{array}{l}\text { The experimental group exposed to } \\
\text { gamification achieved higher scores for the } \\
\text { self-assessment tests and the homework } \\
\text { assignments. Experimental group was more } \\
\text { interested in the activities. }\end{array}$ & $5 / *$ \\
\hline $\begin{array}{l}\text { Kim, } 2013 \text {, Dynamical } \\
\text { model for gamification } \\
\text { of learning (DMGL) }\end{array}$ & South Korea & $\begin{array}{l}\text { Qualitative; Qualitative } \\
\text { analysis of precedent } \\
\text { theories and research, } \\
\text { dozens of explored } \\
\text { elements including } \\
\text { GDF, KCLG, MDA, } \\
\text { etc. }\end{array}$ & Literature Review & $\mathrm{N} / \mathrm{A}$ & $\begin{array}{l}\text { Created a sigmoidal equation for the } \\
\text { educational effectiveness of Gamification. } \\
\text { Game elements play substantial roles not only } \\
\text { in education but also in numerous non-gaming } \\
\text { applications on pc's, smart phones, and tablets. }\end{array}$ & $1 / * * *$ \\
\hline $\begin{array}{l}\text { Kiraly, 2020, The } \\
\text { Effectiveness of a Fully } \\
\text { Gamified Programming } \\
\text { Course after Combining } \\
\text { with Serious Games. }\end{array}$ & Hungary & $\begin{array}{l}\text { Quantitative } \\
\text { non-randomized; } \\
\text { university students } \\
\text { ( } \mathrm{n}=400 ; \mathrm{n}=200 \text { in } \\
\text { experimental group) in } \\
\text { a Learning } \\
\text { Management Systems } \\
\text { course for } 1 \text { semester }\end{array}$ & $\begin{array}{l}\text { Number of students able to } \\
\text { complete both exercises }\end{array}$ & $\begin{array}{l}\text { Points, badges, } \\
\text { incentives, } \\
\text { immediate } \\
\text { feedback and } \\
\text { leaderboards. }\end{array}$ & $\begin{array}{l}\text { More students were able to solve the exercises } \\
\text { after playing the game. }\end{array}$ & $3 / * * *$ \\
\hline $\begin{array}{l}\text { Handani, 2018, } \\
\text { Comparing Learning } \\
\text { Media Applications } \\
\text { Using Gamification } \\
\text { Theory }\end{array}$ & Indonesia & $\begin{array}{l}\text { Mixed method; high } \\
\text { school students } \\
\text { ( } \mathrm{n}=128 \text { ); Literature } \\
\text { review discusses } \\
\text { aspects of intrinsic } \\
\text { motivation, researchers } \\
\text { build two productivity } \\
\text { apps, one which used } \\
\text { these features and one } \\
\text { which didn't }\end{array}$ & $\begin{array}{l}\text { Questionnaires were used } \\
\text { to assess the effects of the } \\
\text { apps. }\end{array}$ & Feedback & $\begin{array}{l}\text { There is no difference in motivation, } \\
\text { self-determination, achievement goals, social } \\
\text { learning and student learning and feedback on } \\
\text { both applications. }\end{array}$ & $5 / *$ \\
\hline $\begin{array}{l}\text { Leftheriotis, } 2017 \text {, } \\
\text { Gamifying informal } \\
\text { learning activities using } \\
\text { interactive displays: an } \\
\text { empirical investigation } \\
\text { of students' learning and } \\
\text { engagement }\end{array}$ & Norway & $\begin{array}{l}\text { Mixed methods; high } \\
\text { school students }(\mathrm{n}=16) \\
\text { engaged with the } \\
\text { application }(45 \mathrm{~min})\end{array}$ & $\begin{array}{l}\text { Pre-post attitudinal surveys } \\
(\mathrm{n}=20) \text { and cognitive tests } \\
\text { along with photos and } \\
\text { observations were recorded }\end{array}$ & Points. & $\begin{array}{l}\text { Most of the studies found in the literature are } \\
\text { focused on the positive effects of an interactive } \\
\text { display (such as a multi-touch screen) on users' } \\
\text { experience. Gamification of a learning activity } \\
\text { improved students' knowledge acquisition, } \\
\text { satisfaction, enjoyment and intention to } \\
\text { participate on similar events in the future. }\end{array}$ & $5 / * * * *$ \\
\hline $\begin{array}{l}\mathrm{Li}, 2018, \text { Can a } \\
\text { Game-based }\end{array}$ & Taiwan & $\begin{array}{l}\text { Quantitative } \\
\text { descriptive; users }\end{array}$ & $\begin{array}{l}\text { Questionnaire on perceived } \\
\text { usefulness }\end{array}$ & $\begin{array}{l}\text { Goals, feedback, } \\
\text { rules, and social }\end{array}$ & $\begin{array}{l}\text { The perceived usefulness is significantly } \\
\text { related to attitude. Most users agree that the }\end{array}$ & $4 / * *$ \\
\hline
\end{tabular}




\begin{tabular}{|c|c|c|c|c|c|c|}
\hline $\begin{array}{l}\text { Productivity Tool } \\
\text { Improve } \\
\text { Procrastination? }\end{array}$ & & $\begin{array}{l}(\mathrm{n}=81) \text { used the } \\
\text { productivity tool app }\end{array}$ & & awareness. & $\begin{array}{l}\text { proposed game-based framework does provide } \\
\text { useful features to avoid procrastination. } \\
\text { Perceived usefulness is not significantly related } \\
\text { to the intention of using the proposed } \\
\text { framework }\end{array}$ & \\
\hline $\begin{array}{l}\text { Laine, 2020, Designing } \\
\text { Engaging Games for } \\
\text { Education: A Systematic } \\
\text { Literature Review on } \\
\text { Game Motivators and } \\
\text { Design Principles }\end{array}$ & $\begin{array}{l}\text { Sweden and } \\
\text { Belgium }\end{array}$ & $\begin{array}{l}\text { Qualitative; studies on } \\
\text { game motivators and } \\
\text { game design principles } \\
(\mathrm{n}=52) \text { from online } \\
\text { databases; Iterative } \\
\text { workflow for data } \\
\text { analysis, comprising } \\
\text { study selection and } \\
\text { quality assessment as } \\
\text { well as data extraction } \\
\text { and synthesis }\end{array}$ & Systematic literature review & N/A & $\begin{array}{l}\text { Motivated engagement is essential in } \\
\text { educational interventions. Many of the } \\
\text { motivators and design principles have strong } \\
\text { support in previous research. Several } \\
\text { taxonomies were identified. The results offer } \\
\text { educational game designers a practical toolkit } \\
\text { that can help promote motivated engagement in } \\
\text { their games. }\end{array}$ & $1 / * * * *$ \\
\hline $\begin{array}{l}\text { Lumsden, 2016, The } \\
\text { effects of gamelike } \\
\text { features and test location } \\
\text { on cognitive test } \\
\text { performance and } \\
\text { participant enjoyment }\end{array}$ & England & $\begin{array}{l}\text { Quantitative } \\
\text { randomized controlled } \\
\text { trial; university staff } \\
\text { and students }(\mathrm{n}=304) \\
\text { took part in either } \\
\text { gamified or } \\
\text { non-gamified variants } \\
\text { of a task }\end{array}$ & $\begin{array}{l}\text { Reaction time, reaction } \\
\text { accuracy, a questionnaire } \\
\text { on enjoyment and } \\
\text { engagement }\end{array}$ & Points & $\begin{array}{l}\text { Points are a highly suitable game mechanic for } \\
\text { gamified cognitive testing and they increase } \\
\text { enjoyment. No evidence that game-like } \\
\text { features could increase engagement to the point } \\
\text { where participant performance improved. }\end{array}$ & $2 / * * *$ \\
\hline $\begin{array}{l}\text { Batooli, 2018, } \\
\text { Information Literacy } \\
\text { Gamified Online } \\
\text { Tutorial }\end{array}$ & Iran & $\begin{array}{l}\text { Qualitative; articles } \\
\text { related to the online } \\
\text { tutorial information } \\
\text { literacy elements } \\
(\mathrm{n}=18) \text { and articles that } \\
\text { addressed motivational } \\
\text { and game strategies } \\
(\mathrm{n}=23) \text {; online tutorials } \\
\text { were reviewed from the } \\
\text { PRIMO database } \\
(\mathrm{n}=81)\end{array}$ & $\begin{array}{l}\text { Literature review; } \\
\text { classification of } 43 \\
\text { essential features for the } \\
\text { creation of an online } \\
\text { tutorial }\end{array}$ & Many & $\begin{array}{l}11 \text { elements of structural and content } \\
\text { gamification and } 28 \text { motivational strategies } \\
\text { were identified to meet the three requirements } \\
\text { of internal competence, autonomy and } \\
\text { relatedness. }\end{array}$ & $1 / * * *$ \\
\hline $\begin{array}{l}\text { Jong, 2018, Gamifying } \\
\text { and Mobilising Social } \\
\text { Enquiry-based Learning } \\
\text { in Authentic Outdoor } \\
\text { Environments }\end{array}$ & Hong Kong & $\begin{array}{l}\text { Mixed methods; grade } \\
10 \text { students ( } \mathrm{n}=559) \\
\text { tested the gamified } \\
\text { application ( } 3 \text { days) }\end{array}$ & $\begin{array}{l}\text { Knowledge test scores and } \\
\text { semi-structured interviews } \\
(45 \mathrm{~min})\end{array}$ & $\begin{array}{l}\text { Avatars, } \\
\text { challenges. }\end{array}$ & $\begin{array}{l}\text { The application had different degrees of } \\
\text { positive effects on the high, moderate, and low } \\
\text { academic-achieving participants. Students in } \\
\text { the gamified condition achieved higher scores } \\
\text { on the test. gamified application promoted } \\
\text { learners' motivation and significantly enhanced } \\
\text { knowledge construction performance. } \\
\text { Promoted cooperation and competition. }\end{array}$ & $5 / * * *$ \\
\hline $\begin{array}{l}\text { Mosalanejad, 2018, } \\
\text { Educational Game: A } \\
\text { Fun and team based } \\
\text { learning in psychiatric } \\
\text { course and its effects on } \\
\text { Learning Indicators }\end{array}$ & Iran & $\begin{array}{l}\text { Quantitative } \\
\text { descriptive; nursing } \\
\text { students }(\mathrm{n}=39) \\
\text { participated in a } \\
\text { psychiatric course }\end{array}$ & $\begin{array}{l}\text { Quasi-experimental studies; } \\
\text { pre-post test } \\
\text { (Questionnaires on learning } \\
\text { readiness, self-regulation, } \\
\text { teamwork, and } \\
\text { self-reflection) }\end{array}$ & N/A & $\begin{array}{l}\text { Gamification can affect the individual and } \\
\text { participation learning by creating an } \\
\text { entertaining and interactive environment. No } \\
\text { significant change in team-based learning. }\end{array}$ & $4 / * * * * *$ \\
\hline $\begin{array}{l}\text { Piras, 2019, Design } \\
\text { Thinking and } \\
\text { Acceptance } \\
\text { Requirements for } \\
\text { Designing Gamified } \\
\text { Software }\end{array}$ & UK and Italy & $\begin{array}{l}\text { Qualitative; four } \\
\text { members of the } \\
\text { research team } \\
\text { conducted post-review } \\
\text { questionnaire to assess } \\
\text { the effectiveness of the } \\
\text { gamification solution }\end{array}$ & $\begin{array}{l}\text { Case study and literature } \\
\text { review; post-study } \\
\text { questionnaire to assess } \\
\text { perceived the usefulness of } \\
\text { DTA }(n=8)\end{array}$ & $\begin{array}{l}\text { Points, badges, } \\
\text { leaderboards. }\end{array}$ & $\begin{array}{l}\text { The analysis of these works provides further } \\
\text { evidences about the practical relevance of the } \\
\text { Design thinking in gamification. }\end{array}$ & $1 / * * * * *$ \\
\hline Mystakidis, 2020, & UK & Qualitative; & Observations (qualitative & Story, points, & Gamified elements elicited students' interest, & $1 / * * * *$ \\
\hline
\end{tabular}




\begin{tabular}{|l|l|l|l|l|l|}
\hline $\begin{array}{l}\text { Distance Education } \\
\text { Gamification in Social } \\
\text { Virtual Reality: A Case } \\
\text { Study on Student } \\
\text { Engagement }\end{array}$ & $\begin{array}{l}\text { post-graduates students } \\
\text { (n=14) participated in } \\
\text { an e-learning course (2 } \\
\text { years) }\end{array}$ & $\begin{array}{l}\text { comparisons between } \\
\text { gamified and non-gamified } \\
\text { conditions) }\end{array}$ & $\begin{array}{l}\text { levels, quests, } \\
\text { classes, badges, } \\
\text { and achievements. }\end{array}$ & $\begin{array}{l}\text { motivation and autonomy towards critical } \\
\text { engagement. }\end{array}$ \\
\hline $\begin{array}{l}\text { Berkling, 2019, } \\
\text { Presenting an } \\
\text { Open-Source Platform } \\
\text { for Supporting Gamified } \\
\text { Class Teaching with Peer } \\
\text { Reviews }\end{array}$ & Germany & Qualitative & $\begin{array}{l}\text { Literature review (analysis } \\
\text { of current literature and } \\
\text { future framework } \\
\text { proposal); Useful quality } \\
\text { data were extracted and } \\
\text { incorporated in a proposal } \\
\text { for a gamification platform }\end{array}$ & $\begin{array}{l}\text { Points, progress, } \\
\text { leaderboards, } \\
\text { tasks, and } \\
\text { immediate } \\
\text { feedback. }\end{array}$ & $\begin{array}{l}\text { A first prototype is implemented that includes } \\
\text { the most important functionalities in order to } \\
\text { be exchanged for the status-quo platform. }\end{array}$ \\
\hline
\end{tabular}

\begin{tabular}{|c|c|c|c|c|c|c|}
\hline $\begin{array}{l}\text { Oluwajana, 2018, The } \\
\text { Adoption of Students' } \\
\text { Hedonic Motivation } \\
\text { System Model to } \\
\text { Gamified Learning } \\
\text { Environment }\end{array}$ & Cyprus & $\begin{array}{l}\text { Mixed methods; } \\
\text { lierature review; } \\
\text { first-year } \\
\text { undergraduate students } \\
\text { ( } \mathrm{n}=150 \text { ) participated in } \\
\text { a gamified learning } \\
\text { environment ( } 5 \text { weeks) }\end{array}$ & $\begin{array}{l}\text { Questionnaire }(\mathrm{n}=27) \text { of } \\
\text { perceived ease of use, } \\
\text { usefulness, behavioural } \\
\text { intention to use, enjoyment, } \\
\text { curiosity, control, and } \\
\text { immersion }\end{array}$ & $\begin{array}{l}\text { Storytelling, } \\
\text { badges, levels, } \\
\text { points, and } \\
\text { rewards. }\end{array}$ & $\begin{array}{l}\text { Perceived usefulness, perceived ease of use, } \\
\text { enjoyment and control all have a significant } \\
\text { positive relationship with behavioural intention } \\
\text { of use and focused immersion. increased } \\
\text { students' motivation and engagement in } \\
\text { learning. Negative relationship exists between } \\
\text { enjoyment and focused immersion. }\end{array}$ & $5 / * * *$ \\
\hline $\begin{array}{l}\text { Ouariachi, 2020, } \\
\text { Gamification } \\
\text { Approaches for } \\
\text { Education and } \\
\text { Engagement on } \\
\text { Pro-Environmental } \\
\text { Behaviors: Searching for } \\
\text { Best Practices }\end{array}$ & Netherlands & $\begin{array}{l}\text { Qualitative; analyzed } \\
\text { cases }(n=6)\end{array}$ & $\begin{array}{l}\text { Literature review and } \\
\text { Triangulation (using two } \\
\text { types of secondary data } \\
\text { analysis and qualitative } \\
\text { content analysis) }\end{array}$ & N/A & $\begin{array}{l}\text { This study concludes that gamification } \\
\text { approaches have potential to educate and } \\
\text { encourage pro-environmental behavioural } \\
\text { change, as long as they combine in their design } \\
\text { extrinsic and intrinsic motivational elements, } \\
\text { short-term and long-term drivers, and game } \\
\text { attributes that encourage taking action in real } \\
\text { life. }\end{array}$ & $1 / * * *$ \\
\hline $\begin{array}{l}\text { Saputro, 2019, A } \\
\text { gamification framework } \\
\text { to enhance students' } \\
\text { intrinsic motivation on } \\
\text { MOOC }\end{array}$ & $\begin{array}{l}\text { Indonesia } \\
\text { and Malaysia }\end{array}$ & $\begin{array}{l}\text { Qualitative; experts } \\
(\mathrm{n}=6) \text { evaluated the } \\
\text { framework }\end{array}$ & $\begin{array}{l}\text { Literature review; relevant } \\
\text { gamification elements } \\
\text { extracted to create a } \\
\text { proposed framework; } \\
\text { evaluation questionnaire on } \\
\text { proposed framework }\end{array}$ & $\begin{array}{l}\text { Challenge, } \\
\text { positive feedback, } \\
\text { transaction, } \\
\text { resource } \\
\text { acquisition, and } \\
\text { feedback. }\end{array}$ & $\begin{array}{l}\text { It is proposed a new gamification framework } \\
\text { to be applied to the MOOC platform that } \\
\text { focuses on efforts to increase students' intrinsic } \\
\text { motivation when taking online courses. }\end{array}$ & $1 / * * * * *$ \\
\hline $\begin{array}{l}\text { Mahmud, 2020, } \\
\text { Teaching Presence in } \\
\text { Online Gamified } \\
\text { Education for } \\
\text { Sustainability Learning }\end{array}$ & Malaysia & $\begin{array}{l}\text { Mixed methods; } \\
\text { quasi-experimental } \\
\text { design; university } \\
\text { students }(\mathrm{n}=48) \text { used a } \\
\text { gamified application }(8 \\
\text { weeks) }\end{array}$ & $\begin{array}{l}\text { Pre-test and post-test } \\
\text { scores, reflections, and } \\
\text { focus group interviews }\end{array}$ & $\begin{array}{l}\text { Points, badges, } \\
\text { leaderboards. }\end{array}$ & $\begin{array}{l}\text { The findings from the quantitative data showed } \\
\text { that the students in the treatment group } \\
\text { obtained higher points for their activities in } \\
\text { JouleBug compared to the control group. } \\
\text { Increment in sustainability knowledge does not } \\
\text { necessarily lead to increment in } \\
\text { pro-environmental behaviour. Recognition by } \\
\text { the teacher was stated to be one of the factors } \\
\text { that motivated students to engage in the } \\
\text { JouleBug activity. }\end{array}$ & $5 / * * *$ \\
\hline $\begin{array}{l}\text { Stachowski, 2019, } \\
\text { Comparison of three } \\
\text { "gamified" exam review } \\
\text { activities }\end{array}$ & USA & $\begin{array}{l}\text { Quantitative } \\
\text { non-randomized; } \\
\text { undergraduate students } \\
\text { ( } \mathrm{n}=60) \text { in a gamified } \\
\text { psychological methods } \\
\text { course ( } 15 \text { weeks) }\end{array}$ & $\begin{array}{l}\text { Exam scores; students } \\
\text { completed a survey } \\
\text { regarding their motivation } \\
\text { and team process and } \\
\text { completed another survey } \\
\text { to indicate whether their } \\
\text { study habits had changed }\end{array}$ & $\begin{array}{l}\text { Points, } \\
\text { leaderboards. }\end{array}$ & $\begin{array}{l}\text { Students rated their motivation for the } \\
\text { activities highly and perceived minimal } \\
\text { relationship conflict during the exercises. All } \\
\text { three review activities are enjoyable and do } \\
\text { appear to have value for students. }\end{array}$ & $3 / * * *$ \\
\hline $\begin{array}{l}\text { Zhang, 2020, } \\
\text { Game-based } \\
\text { self-regulated language } \\
\text { learning: Theoretical } \\
\text { analysis and } \\
\text { bibliometrics }\end{array}$ & Hong Kong & $\begin{array}{l}\text { Qualitative; } 54 \text { papers } \\
\text { in the database on } \\
\text { GBLL and } 314 \text { papers } \\
\text { in the database on } \\
\text { SRLL }\end{array}$ & $\begin{array}{l}\text { Theoretical analysis, } \\
\text { thematic evolution analysis, } \\
\text { and social network analysis }\end{array}$ & N/A & $\begin{array}{l}\text { The results show that GBSRLL is a new } \\
\text { interdisciplinary field that has been attracting } \\
\text { increasing academic attention since the period } \\
\text { from } 2018 \text { to } 2019 \text {. The prominent research } \\
\text { topics in this field include self-regulated } \\
\text { learning strategies that can be performed in }\end{array}$ & $1 / * * * * *$ \\
\hline
\end{tabular}




\begin{tabular}{|c|c|c|c|c|c|c|}
\hline & & & & & $\begin{array}{l}\text { GBLL, the effects of GBSRLL on learners' } \\
\text { affective states, and the features of GBSRLL. }\end{array}$ & \\
\hline $\begin{array}{l}\text { Hsieh, 2014, Motivation } \\
\text { matters? The relationship } \\
\text { among different types of } \\
\text { learning motivation, } \\
\text { engagement behaviors } \\
\text { and learning outcomes of } \\
\text { undergraduate students } \\
\text { in Taiwan }\end{array}$ & Taiwan & $\begin{array}{l}\text { Quantitative } \\
\text { descriptive; junior } \\
\text { university students } \\
(\mathrm{n}=231) \text { for one } \\
\text { semester }\end{array}$ & Survey results & N/A & $\begin{array}{l}\text { The outcomes from this hierarchical multiple } \\
\text { regression analysis show that three different } \\
\text { student engagement behaviors do not } \\
\text { significantly predict learning outcomes when } \\
\text { including the variables of student's } \\
\text { demographic backgrounds and learning } \\
\text { motivation. }\end{array}$ & $4 / * * *$ \\
\hline $\begin{array}{l}\text { Gibson, 2013, Digital } \\
\text { badges in education }\end{array}$ & USA & Qualitative & $\begin{array}{l}\text { Literature Review; } \\
\text { information regarding } \\
\text { origin, history, and } \\
\text { evidence of use with digital } \\
\text { badges }\end{array}$ & Badges. & $\begin{array}{l}\text { Because digital badges seem to have important } \\
\text { impacts on motivation for learning, status } \\
\text { within a community, and can transparently } \\
\text { display achievement level, validation } \\
\text { processes and directly link to rich media } \\
\text { evidence, the research implications are quite } \\
\text { broad and varied. The potential seems high for } \\
\text { a transformative moment in the history of } \\
\text { technology in teaching and learning. }\end{array}$ & $1 / * * * *$ \\
\hline $\begin{array}{l}\text { Dominguez, 2013, } \\
\text { Gamifying learning } \\
\text { experiences: Practical } \\
\text { implications and } \\
\text { outcomes }\end{array}$ & Spain & $\begin{array}{l}\text { Randomized Control } \\
\text { Trial; } 1 \text { st and } 2 \text { nd year } \\
\text { university students, } \\
\text { control group }(n=80) \text {, } \\
\text { experimental }(n=131)\end{array}$ & $\begin{array}{l}\text { Attitudinal survey, tests, } \\
\text { presentations, final exam, } \\
\text { surveys }\end{array}$ & $\begin{array}{l}\text { Badges, challenges } \\
\text { and leaderboards. }\end{array}$ & $\begin{array}{l}\text { Some common beliefs about the benefits } \\
\text { obtained when using games in education can } \\
\text { be challenged. Students who completed the } \\
\text { gamified experience got better scores in } \\
\text { practical assignments and in overall score, but } \\
\text { the findings also suggest that these students } \\
\text { performed poorly on written assignments and } \\
\text { participated less on class activities, although } \\
\text { their initial motivation was higher. }\end{array}$ & $2 / * *$ \\
\hline $\begin{array}{l}\text { Morrison, 2014, Khan } \\
\text { Academy Gamifies } \\
\text { Computer Science }\end{array}$ & USA & $\begin{array}{l}\text { Qualitative: keywords: } \\
\text { "Khan Academy, } \\
\text { motivation, } \\
\text { gamification", }\end{array}$ & $\begin{array}{l}\text { Literature Review; } \\
\text { information content, } \\
\text { learning environment, } \\
\text { gamification techniques } \\
\text { (badges, knowledge map, } \\
\text { progress indicators, etc) }\end{array}$ & $\begin{array}{l}\text { Map, badges, } \\
\text { goals, and progress } \\
\text { indicators. }\end{array}$ & $\begin{array}{l}\text { There are qualities that make it ideal for novice } \\
\text { informal learners that are self-motivated, } \\
\text { addressing issues of short-term engagement } \\
\text { and seeks to use gamification to keep learners } \\
\text { engaged and moving forward to more difficult } \\
\text { tasks. Khan has missed critical motivational } \\
\text { elements in the application of gamification that } \\
\text { might dramatically improve the quality of the } \\
\text { gaming elements and increase motivation. }\end{array}$ & $1 / * * *$ \\
\hline $\begin{array}{l}\text { Barata, 2014, Engaging } \\
\text { Engineering Students } \\
\text { with Gamification }\end{array}$ & Portugal & $\begin{array}{l}\text { Quantitative } \\
\text { non-randomized; } 2 \\
\text { semesters of MSc } \\
\text { course, } 42 \text { students in } \\
\text { the } 1 \text { st year (control) } \\
\text { and } 35 \text { in the } 2 \mathrm{nd} \\
\text { (experimental) }\end{array}$ & $\begin{array}{l}\text { Number of lecture } \\
\text { Downloads, Number of } \\
\text { Posts, Attendance and } \\
\text { Grades, Student Feedback }\end{array}$ & $\begin{array}{l}\text { Scoring, levels, } \\
\text { leaderboards, } \\
\text { challenges, and } \\
\text { badges. }\end{array}$ & $\begin{array}{l}\text { Results were very encouraging, showing } \\
\text { significant increases ranging from lecture } \\
\text { attendance to online participation, proactive } \\
\text { behaviors and perusing the course reference } \\
\text { materials. Moreover, students considered the } \\
\text { gamified instance to be more motivating, } \\
\text { interesting and easier to learn as compared to } \\
\text { other courses. }\end{array}$ & $3 / * * * *$ \\
\hline $\begin{array}{l}\text { Berkling, 2013, } \\
\text { Gamification of a } \\
\text { software engineering } \\
\text { course }\end{array}$ & Germany & $\begin{array}{l}\text { Quantitative } \\
\text { descriptive; 2nd year } \\
\text { University students } \\
\text { taking Software } \\
\text { Engineering }(\mathrm{n}=90)\end{array}$ & $\begin{array}{l}\text { Feedback was collected } \\
\text { through a built-in form } \\
\text { within the } \\
\text { application. }\end{array}$ & $\begin{array}{l}\text { Points, Levels, } \\
\text { Paths and } \\
\text { Progress, } \\
\text { Challenges, } \\
\text { Immediate } \\
\text { Feedback, and } \\
\text { leaderboards. }\end{array}$ & $\begin{array}{l}\text { Students did not seem to be ready for } \\
\text { autonomy, mastery was not perceived to be } \\
\text { relevant and the purpose of starting project } \\
\text { work as well as good preparation for the exam } \\
\text { seemed unattainable to the students. } \\
\text { Gamification was viewed as unnecessary } \\
\text { hindrance towards studying for the exams and } \\
\text { self-regulation and the ability to schedule the } \\
\text { material across the semester was lacking } \\
\text { despite a number of proposed schedules that } \\
\text { were suggested by the lecturer but not } \\
\text { enforced. Even attending lecture was not }\end{array}$ & $4 / * * *$ \\
\hline
\end{tabular}




\begin{tabular}{|c|c|c|c|c|c|c|}
\hline & & & & & $\begin{array}{l}\text { enforced. This was not welcomed by all } \\
\text { students, who were looking for that kind of } \\
\text { structure. }\end{array}$ & \\
\hline $\begin{array}{l}\text { Connolly, 2012, A } \\
\text { systematic literature } \\
\text { review of empirical } \\
\text { evidence on computer } \\
\text { games and serious games }\end{array}$ & Scotland & $\begin{array}{l}\text { Qualitative: } 129 \text { papers } \\
\text { were identified on } \\
\text { positive impacts of } \\
\text { games on users over } 14 \\
\text { years. }\end{array}$ & $\begin{array}{l}\text { Literature Review: The } \\
\text { outcomes and impacts of } \\
\text { playing games were } \\
\text { analysed in terms of several } \\
\text { variables. }\end{array}$ & N/A & $\begin{array}{l}\text { It seems that, despite the overwhelming } \\
\text { publicity given to the negative impact of } \\
\text { games, like most technologies before them, } \\
\text { computer games can have both positive and } \\
\text { negative impacts. The results show that studies } \\
\text { of games for learning and serious games } \\
\text { tended to use quasi-experimental designs with } \\
\text { surveys less common, while studies of } \\
\text { entertainment games used quasi-experiments } \\
\text { and surveys. RCTs and qualitative designs } \\
\text { were relatively uncommon. }\end{array}$ & $1 / * * * * *$ \\
\hline $\begin{array}{l}\text { Devedzic, } 2015 \text {, } \\
\text { Developing Open } \\
\text { Badges: a comprehensive } \\
\text { approach }\end{array}$ & Serbia & $\begin{array}{l}\text { Qualitative Framework } \\
\text { of different } \\
\text { perspectives on badges }\end{array}$ & Literature Review & Badges & $\begin{array}{l}\text { Different perspectives on badge systems } \\
\text { enable a clearer and more complete } \\
\text { understanding than if one focuses only on a } \\
\text { single perspective. Different stakeholders have } \\
\text { different interests and concerns in badges. } \\
\text { Without a deep insight into a number of these } \\
\text { interests and concerns, it is difficult to acquire } \\
\text { a good understanding of this thriving field. }\end{array}$ & $1 / * *$ \\
\hline $\begin{array}{l}\text { Barata, 2015, } \\
\text { Gamification for smarter } \\
\text { learning: Tales from the } \\
\text { trenches }\end{array}$ & Portugal & $\begin{array}{l}\text { Mixed methods; First } \\
\text { year }(n=35), \text { second } \\
\text { year }(n=52) \text {, across } 2 \\
\text { years }\end{array}$ & $\begin{array}{l}\text { Student grades and } \\
\text { feedback questionnaires }\end{array}$ & $\begin{array}{l}\text { Points, badges, } \\
\text { leaderboards, } \\
\text { challenges, and } \\
\text { quests. }\end{array}$ & $\begin{array}{l}\text { Results show that students participate more in } \\
\text { activities with gamification and also report the } \\
\text { course as being both more motivating and } \\
\text { interesting than non-gamified courses. }\end{array}$ & $5 / * * *$ \\
\hline $\begin{array}{l}\text { Hanus, 2015, Assessing } \\
\text { the effects of } \\
\text { gamification in the } \\
\text { classroom: A } \\
\text { longitudinal } \\
\text { study on intrinsic } \\
\text { motivation, social } \\
\text { comparison, satisfaction, } \\
\text { effort, } \\
\text { and academic } \\
\text { performance }\end{array}$ & USA & $\begin{array}{l}\text { Non-randomized } \\
\text { control trial; } 2 \\
\text { university courses }(\mathrm{n}= \\
80)\end{array}$ & $\begin{array}{l}\text { Video game habits surveys, } \\
\text { intrinsic motivation } \\
\text { inventory, class satisfaction } \\
\text { survey, class effort survey, } \\
\text { learner empowerment } \\
\text { survey, social comparison } \\
\text { scale, and final exam scores }\end{array}$ & $\begin{array}{l}\text { Leaderboards, } \\
\text { badges. }\end{array}$ & $\begin{array}{l}\text { Our results found that students in the gamified } \\
\text { course showed less motivation, } \\
\text { satisfaction, and empowerment over time than } \\
\text { those in the non-gamified class. }\end{array}$ & $3 / * * * *$ \\
\hline $\begin{array}{l}\text { Herreria-Alonso, 2016, } \\
\text { An open-source platform } \\
\text { for using gamification } \\
\text { and social learning } \\
\text { methodologies in } \\
\text { engineering education: } \\
\text { Design and experience }\end{array}$ & Spain & $\begin{array}{l}\text { Mixed-methods, } \\
\text { ambiguous number of } \\
\text { students }(\mathrm{n}=?),\end{array}$ & $\begin{array}{l}\text { Exam scores, satisfaction } \\
\text { poll, Dependence between } \\
\text { continuous assessment and } \\
\text { games and pass/fail the } \\
\text { subject, Behavior of } \\
\text { non-fresh students }\end{array}$ & $\begin{array}{l}\text { Rewards, badges, } \\
\text { reputation, and } \\
\text { social ranking } \\
\text { system. }\end{array}$ & $\begin{array}{l}\text { We argue that this approach, together with } \\
\text { gamification elements, is helpful in increasing } \\
\text { the students' motivation, besides improving } \\
\text { the learning experience and performance. }\end{array}$ & $1 / *$ \\
\hline $\begin{array}{l}\text { Ahn, 2014, Open badges } \\
\text { for education: What are } \\
\text { the implications at the } \\
\text { intersection of open } \\
\text { systems and badging? }\end{array}$ & USA & $\begin{array}{l}\text { Qualitative; we } \\
\text { considered three } \\
\text { characteris-tics of } \\
\text { badges (motivation, } \\
\text { pedagogy and } \\
\text { credential) and three } \\
\text { components of } \\
\text { open(production, } \\
\text { access and } \\
\text { appropriation) }\end{array}$ & $\begin{array}{l}\text { Literature review, } \\
\text { information regarding } \\
\text { badges and open systems }\end{array}$ & Badges & $\begin{array}{l}\text { The idea of badges as a pedagogical tool and } \\
\text { badges as credential may in fact be specialized } \\
\text { instantiations of badges as a motivator of some } \\
\text { type of behaviour. Badges may promote } \\
\text { intrinsically motivated behaviours such as } \\
\text { seeking out feedback and guidance through a } \\
\text { learning pathway if interpreted as an artefact to } \\
\text { encourage particular teaching and learning } \\
\text { activities. }\end{array}$ & $1 / * * *$ \\
\hline $\begin{array}{l}\text { Santos, 2013, Evaluating } \\
\text { the Use of Open Badges } \\
\text { in an Open Learning }\end{array}$ & Belgium & $\begin{array}{l}\text { Quantitative } \\
\text { Descriptive; masters } \\
\text { students }(n=26)\end{array}$ & $\begin{array}{l}\text { Survey to assess the } \\
\text { effectiveness of the } \\
\text { platform, google site }\end{array}$ & $\begin{array}{l}\text { Badges, social } \\
\text { visualization, and } \\
\text { activity stream. }\end{array}$ & $\begin{array}{l}\text { We conclude that the mere fact of tracking } \\
\text { student activity and making it public through } \\
\text { student activity such as activity streams, }\end{array}$ & $4 / * * * *$ \\
\hline
\end{tabular}




\begin{tabular}{|c|c|c|c|c|c|c|}
\hline Environment & & $\begin{array}{l}\text { development and } \\
\text { evaluation of an OLE }\end{array}$ & analytics & & $\begin{array}{l}\text { tabular and badge overviews may motivate } \\
\text { activity such as reading. Social visualisations } \\
\text { such as StepUp! and Navi may trigger more } \\
\text { explicit activity such as commenting and } \\
\text { tweeting. Moreover, badges motivated } \\
\text { students. }\end{array}$ & \\
\hline $\begin{array}{l}\text { Kingsley, 2015, } \\
\text { Gamification }\end{array}$ & USA & $\begin{array}{l}\text { Mixed-methods; data } \\
\text { collection over } 4 \\
\text { weeks, students in an } \\
\text { elementary class ( } \mathrm{n}= \\
47)\end{array}$ & $\begin{array}{l}\text { Classroom observations, } \\
\text { analysis of the gamified } \\
\text { learning environment, } \\
\text { semistructured interviews } \\
\text { with the teacher, } \\
\text { and a survey of students }\end{array}$ & $\begin{array}{l}\text { Points, badges, } \\
\text { levels, and awards. }\end{array}$ & $\begin{array}{l}\text { There is a potential for gamification to become } \\
\text { a constructive force in education by supporting } \\
\text { new literacies involving creativity, critical } \\
\text { thinking, collaboration, and communication. } \\
\text { To ensure meaningful approaches for } \\
\text { technological practices, there is a need to align } \\
\text { instruction to the ethos of new literacies. }\end{array}$ & $5 / *$ \\
\hline
\end{tabular}

\begin{tabular}{|c|c|c|c|c|c|c|}
\hline $\begin{array}{l}\text { Kiryakova, } 2014, \\
\text { Gamification in } \\
\text { education }\end{array}$ & Bulgaria & Qualitative & Literature review & $\begin{array}{l}\text { Avatar, progress, } \\
\text { levels, feedback, } \\
\text { badges, and } \\
\text { leaderboards. }\end{array}$ & $\begin{array}{l}\text { Gamification is an effective approach to make } \\
\text { positive change in students' behavior and } \\
\text { attitude towards learning, to improve their } \\
\text { motivation and engagement. The results of the } \\
\text { change have bilateral nature - they can affect } \\
\text { students' results and understanding of the } \\
\text { educational content and create conditions for } \\
\text { an effective learning process. }\end{array}$ & $2 / * *$ \\
\hline $\begin{array}{l}\text { De-Marcos, 2014, An } \\
\text { empirical study } \\
\text { comparing gamification } \\
\text { and social networking on } \\
\text { e-learning }\end{array}$ & Spain & $\begin{array}{l}\text { Quantitative } \\
\text { non-randomized; first } \\
\text { year undergraduates } \\
\text { ( } \mathrm{n}=114) \text {, not randomly } \\
\text { assigned to } 3 \text { groups, } \\
\text { 3rd was control }\end{array}$ & $\begin{array}{l}\text { Interactive tests }=\text { pre-test } \\
\text { performance. Post-test }= \\
\text { assignment scores, final } \\
\text { examination and a } \\
\text { participation score for each } \\
\text { participant, attitudinal } \\
\text { survey }\end{array}$ & $\begin{array}{l}\text { Levels, challenge, } \\
\text { rewards, badges, } \\
\text { leaderboards, and } \\
\text { discussion forums. }\end{array}$ & $\begin{array}{l}\text { Results suggest that the proposed instruments } \\
\text { improve students' performance on practical } \\
\text { assignments related to skill acquisition. } \\
\text { Average performance improved in each } \\
\text { experimental group even with low } \\
\text { participation rates affecting the whole group } \\
\text { significantly. }\end{array}$ & $3 / * * *$ \\
\hline $\begin{array}{l}\text { De-Marcos, 2016, On the } \\
\text { effectiveness of } \\
\text { game-like and social } \\
\text { approaches in learning: } \\
\text { Comparing educational } \\
\text { gaming, gamification \& } \\
\text { social networking }\end{array}$ & Spain & $\begin{array}{l}\text { Quantitative } \\
\text { non-randomized; } \\
\text { first-year } \\
\text { undergraduate students } \\
\text { (n=379), } 4 \text { treatment } \\
\text { groups, one control } \\
\text { group, over } 10 \text { weeks } \\
\text { in a blended-learning } \\
\text { course }\end{array}$ & $\begin{array}{l}\text { The course had five } \\
\text { evaluation items: four } \\
\text { practical assignments and } \\
\text { one final examination. }\end{array}$ & $\begin{array}{l}\text { Challenges, levels, } \\
\text { points, narrative, } \\
\text { Trophies, badges, } \\
\text { leaderboards, and } \\
\text { rewards. }\end{array}$ & $\begin{array}{l}\text { Results suggest that all experimental } \\
\text { conditions significantly impact on learning } \\
\text { performance. Moderate differences were also } \\
\text { found when experimental conditions were } \\
\text { compared suggesting that social networking } \\
\text { and social gamification produced better results } \\
\text { even at early stages of the course (week 3). } \\
\text { The effects on the different kinds of evaluation } \\
\text { items were also studied and we found that in a } \\
\text { final examination designed to assess } \\
\text { conceptual knowledge, the new approaches } \\
\text { did not yield any benefit when compared with } \\
\text { a control group. Students that used the } \\
\text { educational game, the gamification plugin and } \\
\text { social network performed poorly when } \\
\text { compared with the social gamification and } \\
\text { control (blended-learning) groups. Social } \\
\text { gamification returned better results in terms of } \\
\text { immediacy across } \\
\text { different evaluation items }\end{array}$ & $3 / * * * *$ \\
\hline $\begin{array}{l}\text { Haaranen, 2014, } \\
\text { Software Architectures } \\
\text { for Implementing } \\
\text { Achievement Badges - } \\
\text { Practical Experiences }\end{array}$ & Finland & $\begin{array}{l}\text { Qualitative; } \\
\text { examination of } 2 \text { past } \\
\text { quasi-experimental } \\
\text { papers }\end{array}$ & $\begin{array}{l}\text { Literature review; data } \\
\text { extracted from past papers }\end{array}$ & Badges . & $\begin{array}{l}\text { Six design principles were constructed to } \\
\text { guide in the creation of the new badge system. } \\
\text { 1) Functional requirements. The badge system } \\
\text { should be able to divide the badges into three } \\
\text { main components - signifiers as the visual } \\
\text { artefacts seen by the users, completion logic } \\
\text { which determines when a badge is awarded, } \\
\text { and reward that is the value of badges to their } \\
\text { wearers. 2) Interoperability. The system needs }\end{array}$ & $1 / * * *$ \\
\hline
\end{tabular}




\begin{tabular}{|c|c|c|c|c|c|c|}
\hline & & & & & $\begin{array}{l}\text { to be compatible with the existing Learning } \\
\text { Management Systems. 3) Security. The core } \\
\text { functionality of the LMS should never be } \\
\text { compromised even in cases of failure in badge } \\
\text { system in use. 4) Flexibility. Using the system } \\
\text { in multiple courses should be taken into } \\
\text { account. This would also mean that students } \\
\text { could share and compare badges amongst } \\
\text { peers, if they so wished. 5) Privacy. The } \\
\text { system should not distribute private } \\
\text { information about the students to third parties. } \\
\text { 6) Usability. The system should be simple and } \\
\text { effortless to use and it should integrate well } \\
\text { into the general look and feel of the LMS. }\end{array}$ & \\
\hline $\begin{array}{l}\text { Haaranen, 2015, How } \\
\text { (not) to Introduce Badges } \\
\text { to Online Exercises }\end{array}$ & Finland & $\begin{array}{l}\text { Quantitative } \\
\text { Descriptive; follow-up } \\
\text { to a previous study. } \\
\text { Student respondents (n } \\
=306 \text { ) }\end{array}$ & Survey results & $\begin{array}{l}\text { Badges, points, } \\
\text { and levels. }\end{array}$ & $\begin{array}{l}\text { We found that some students have strongly } \\
\text { negative emotions towards badges. Therefore, } \\
\text { one should make } \\
\text { it technically easy to opt out from badges or } \\
\text { make them opt in. Additionally, our badges } \\
\text { did not affect grading, but feedback from } \\
\text { points and badges can confuse students. } \\
\text { Therefore, one should give students clear } \\
\text { instructions what else, if anything, is affected } \\
\text { by badges. }\end{array}$ & $4 / * * * *$ \\
\hline $\begin{array}{l}\text { Pedro, 2015, } \\
\text { Peer-supported badge } \\
\text { attribution in a } \\
\text { collaborative learning } \\
\text { platform: The SAPO } \\
\text { Campus case }\end{array}$ & Portugal & $\begin{array}{l}\text { Quantitative } \\
\text { Descriptive; SAPO } \\
\text { campus, } 1 \text { academic } \\
\text { year, all students and } \\
\text { teachers involved }\end{array}$ & $\begin{array}{l}\text { Number of badges } \\
\text { awarded }\end{array}$ & Badges. & $\begin{array}{l}\text { Earning badges has contributed for users to } \\
\text { feel more engaged with specific tasks or } \\
\text { activities in the platform. The results of the } \\
\text { aforementioned pilot test may be understood } \\
\text { as a starting point to a deeper analysis about } \\
\text { the meaning and role of badges in promoting } \\
\text { motivation and providing new ways of } \\
\text { assessment }\end{array}$ & $4 / *$ \\
\hline $\begin{array}{l}\text { Leaning 2015, A study of } \\
\text { the use of games and } \\
\text { gamification to enhance } \\
\text { student engagement, } \\
\text { experience and } \\
\text { achievement on a } \\
\text { theory-based course of an } \\
\text { undergraduate media } \\
\text { degree }\end{array}$ & UK & $\begin{array}{l}\text { Mixed; media theory } \\
\text { course at Winchester } \\
\text { University, ambiguous } \\
\text { number of students, } \\
\text { two academic years }\end{array}$ & $\begin{array}{l}\text { Mean marks, attitudinal } \\
\text { surveys, student feedback } \\
\text { forms }\end{array}$ & leaderboards & $\begin{array}{l}\text { While the qualitative data from the focus } \\
\text { groups and the module feedback forms } \\
\text { indicate that students were enjoying the } \\
\text { course more, were reporting putting in more } \\
\text { effort in terms of their preparation and } \\
\text { even felt that there were learning to a deeper } \\
\text { level the comparison of mean grades } \\
\text { indicated only a small and not statistically } \\
\text { significant difference. }\end{array}$ & $5 / * * *$ \\
\hline $\begin{array}{l}\text { Sanmugam, 2016, The } \\
\text { Impacts of infusing Game } \\
\text { elements and } \\
\text { Gamification in learning }\end{array}$ & Malaysia & $\begin{array}{l}\text { Mixed-methods; } \\
\text { eight-week } \\
\text { intervention, points, } \\
\text { badges, and } \\
\text { leaderboards, unnamed } \\
\text { number of students ( } \\
=\text { ?) }\end{array}$ & $\begin{array}{l}\text { Overall tally of } \\
\text { points/leaderboard and } \\
\text { badges; 3-stage interviews }\end{array}$ & $\begin{array}{l}\text { Points, badges, } \\
\text { levels, and } \\
\text { leaderboards. }\end{array}$ & $\begin{array}{l}\text { The findings based on the interviews with the } \\
\text { participants found all the elements played a } \\
\text { part in engaging the interest of students in } \\
\text { learning, more so badges and leaderboard. It } \\
\text { was also identified that certain elements are } \\
\text { preferred to acquire either online or offline }\end{array}$ & $5 / * * *$ \\
\hline $\begin{array}{l}\text { Monterrat, 2015, A } \\
\text { Player Model for } \\
\text { Adaptive Gamification in } \\
\text { Learning Environments }\end{array}$ & France & $\begin{array}{l}\text { Quantitative } \\
\text { Descriptive; } 420 \text { users }\end{array}$ & $\begin{array}{l}\text { Survey results and number } \\
\text { of hours spent on task }\end{array}$ & $\begin{array}{l}\text { Points, badges, } \\
\text { and leaderboards. }\end{array}$ & $\begin{array}{l}\text { An experiment has proven the effec-tiveness } \\
\text { of the experts-based matrix, as the members of } \\
\text { the group with adapted fea-tures spent } 39 \% \\
\text { more time on the learning environment than } \\
\text { the members of the group with } \\
\text { counter-adapted features. }\end{array}$ & $4 / * *$ \\
\hline $\begin{array}{l}\text { Nah, 2013, Gamification } \\
\text { of Education Using } \\
\text { Computer Games }\end{array}$ & USA & $\begin{array}{l}\text { Qualitative; identify } 5 \\
\text { main gamification } \\
\text { principles: (i) Goal }\end{array}$ & $\begin{array}{l}\text { Literature Review; extracts } \\
\text { relevant features to achieve } \\
\text { each of the gamification }\end{array}$ & $\begin{array}{l}\text { leaderboards, } \\
\text { levels, points, } \\
\text { onboarding, }\end{array}$ & Gamification Framework, see paper & $1 / * * * *$ \\
\hline
\end{tabular}




\begin{tabular}{|c|c|c|c|c|c|c|}
\hline & & $\begin{array}{l}\text { orientation; (ii) } \\
\text { Achievement, (ii) } \\
\text { Reinforcement, (iv) } \\
\text { Competition, and } \\
\text { (v) Fun orientation }\end{array}$ & principles & $\begin{array}{l}\text { challenges, quests, } \\
\text { badges, immediate } \\
\text { feedback, social } \\
\text { engagement loops, } \\
\text { teams, rules, } \\
\text { marketplaces, } \\
\text { economies, } \\
\text { visuals, sounds, } \\
\text { avatars, } \\
\text { customization, } \\
\text { narrative, and } \\
\text { roleplay. }\end{array}$ & & \\
\hline $\begin{array}{l}\text { Nicholson, 2015, A } \\
\text { recipe for meaningful } \\
\text { gamification }\end{array}$ & Switzerland & $\begin{array}{l}\text { Qualitative; Develops } \\
6 \text { concept framework } \\
\text { using existing } \\
\text { literature }\end{array}$ & $\begin{array}{l}\text { Literature review, } \\
\text { classifies info using } \\
\text { framework }\end{array}$ & N/A & $\begin{array}{l}\text { This article introduces six concepts - } \\
\text { Reflection, Exposition, Choice, Information, } \\
\text { Play, and Engagement - to guide designers of } \\
\text { gamification systems that rely on } \\
\text { non-reward-based game elements to help } \\
\text { people find personal connections and meaning } \\
\text { in a real world context. }\end{array}$ & $1 / * * * *$ \\
\hline $\begin{array}{l}\text { McDaniel, 2015, How to } \\
\text { Design Experimental } \\
\text { Research Studies around } \\
\text { Digital Badges }\end{array}$ & USA & $\begin{array}{l}\text { Qualitative; literature } \\
\text { review guides } \\
\text { framework } \\
\text { development, } \\
\text { ambiguous number of } \\
\text { databases/studies }\end{array}$ & $\begin{array}{l}\text { Literature Review; } \\
\text { assimilates extracted } \\
\text { research to develop an } \\
\text { experimental design }\end{array}$ & Badges. & $\begin{array}{l}\text { Although recent years have generated exciting } \\
\text { insights and ideas about digital badging, future } \\
\text { research will continue to illustrate the precise } \\
\text { conditions in which digital badges thrive. } \\
\text { Sound research design will help us to design } \\
\text { the experiments that collect the empirical data } \\
\text { that help us to outline these conditions. }\end{array}$ & $1 / * * *$ \\
\hline $\begin{array}{l}\text { Stott, 2013, Analysis of } \\
\text { gamification in education }\end{array}$ & Canada & $\begin{array}{l}\text { Qualitative; } \\
\text { exploration of } 3 \\
\text { gamification cases. } \\
\text { The first study; } \\
\text { university classroom } \\
\text { ( } \mathrm{n}=200) \text {, the second; } \\
\text { real world game } \\
\text { developed for } 400 \text { RIT } \\
\text { students, university } \\
\text { class of } 70 \text { students }\end{array}$ & $\begin{array}{l}\text { Analysis of } 3 \text { case studies, } \\
\text { extracts data regarding the } \\
\text { universality of } \\
\text { gamification }\end{array}$ & $\begin{array}{l}\text { Freedom to fail, } \\
\text { rapid feedback, } \\
\text { progression, and } \\
\text { storytelling. }\end{array}$ & $\begin{array}{l}\text { These three case studies are useful in seeing } \\
\text { how theoretical 'best practices' in the } \\
\text { gamification of education are extremely } \\
\text { context sensitive. There is no once-size-fits all } \\
\text { model for the successful gamification of a } \\
\text { classroom. }\end{array}$ & $1 / * * * *$ \\
\hline $\begin{array}{l}\text { Todor, 2013, The } \\
\text { Gamification of the Study } \\
\text { of Electronics in } \\
\text { Dedicated e-Learning } \\
\text { Platforms }\end{array}$ & Romania & $\begin{array}{l}\text { Qualitative; } \\
\text { observations regarding } \\
\text { the use of an } \\
\text { e-learning platform }\end{array}$ & $\begin{array}{l}\text { Observations and feedback } \\
\text { are collected }\end{array}$ & $\begin{array}{l}\text { Points, } \\
\text { leaderboards, } \\
\text { feedback, and } \\
\text { badges. }\end{array}$ & $\begin{array}{l}\text { There was a major increase of the interest for } \\
\text { the course. Furthermore, they wanted to make } \\
\text { a contribution in improving the gamified } \\
\text { structures, suggesting more interactive tests, } \\
\text { new ways of rewarding or proposing new } \\
\text { projects and practical applications. Another } \\
\text { aspect noticed from the students was the way } \\
\text { they showed their positive competitiveness. }\end{array}$ & $1 / *$ \\
\hline $\begin{array}{l}\text { Garcia-Iruela, } 2019, \\
\text { Analysis of Gamification } \\
\text { Elements. A Case Study } \\
\text { in a Computer Science } \\
\text { Course }\end{array}$ & Spain & $\begin{array}{l}\text { Randomized Control } \\
\text { Trial; faculty of } \\
\text { sciences at Lisbon } \\
\text { University ( } \mathrm{n}=200), 4 \\
\text { week intervention, two } \\
\text { groups (students } \\
\text { randomly assigned) } \\
\text { group one was control } \\
\text { for the first two weeks, } \\
\text { and group two for the } \\
\text { last two weeks }\end{array}$ & $\begin{array}{l}\text { Midway and post-test } \\
\text { survey }\end{array}$ & $\begin{array}{l}\text { Points, badges, } \\
\text { leaderboards, } \\
\text { levels, progress } \\
\text { bar and } \\
\text { classification. }\end{array}$ & $\begin{array}{l}\text { The data collected showed a slightly higher } \\
\text { satisfaction of students belonging to a } \\
\text { gamified course versus students in a } \\
\text { non-gamified course. In group one the } \\
\text { satisfaction fell when they stopped being } \\
\text { gamified, while satisfaction in group two went } \\
\text { up in the second part when they started to be } \\
\text { gamified. The data obtained reflects that } \\
\text { gamification achieves a slightly higher } \\
\text { satisfaction among students. This small } \\
\text { difference may be due to the short period of } \\
\text { time used. }\end{array}$ & $2 / * *$ \\
\hline Hakulinin, 2015, The & Finland & Randomized Control & Scores from computer & Badges, & Achievement badges had a statistically & $2 / * *$ \\
\hline
\end{tabular}




\begin{tabular}{|c|c|c|c|c|}
\hline $\begin{array}{l}\text { Effect of Achievement } \\
\text { Badges on Students' } \\
\text { Behavior: An Empirical } \\
\text { Study in a } \\
\text { University-Level } \\
\text { Computer Science } \\
\text { Course }\end{array}$ & $\begin{array}{l}\text { Trial; Data Structures } \\
\text { and Algorithms course } \\
\text { students }(\mathrm{n}=281), \\
\text { over one semester, } \\
\text { randomly assigned to } \\
\text { each group }\end{array}$ & $\begin{array}{l}\text { science exercises, total } \\
\text { time in TRAKLA2, and } \\
\text { mean number of badges. } \\
\text { Open-ended feedback }\end{array}$ & $\begin{array}{l}\text { leaderboards, and } \\
\text { immediate } \\
\text { feedback. }\end{array}$ & $\begin{array}{l}\text { significant impact on some aspects of } \\
\text { students' behavior, and that students had } \\
\text { generally positive attitudes towards them. } \\
\text { Students who had the badges spent more time } \\
\text { per exercise. Students in the treatment group } \\
\text { also had a higher number of sessions in the } \\
\text { learning environment. The majority of the } \\
\text { students reported being motivated by the } \\
\text { badges }\end{array}$ \\
\hline
\end{tabular}




\section{Supplementary Files}

This is a list of supplementary files associated with this preprint. Click to download.

- SupplementalFiles1.pdf 